\title{
Review on additive manufacturing of tooling for hot stamping
}

\author{
Dimitrios Chantzis ${ }^{1} \cdot$ Xiaochuan Liu $^{1} \cdot$ Denis J. Politis $^{2} \cdot$ Omer El Fakir $^{1} \cdot$ Teun Yee Chua $^{1} \cdot$ Zhusheng Shi $^{1}$. \\ Liliang Wang ${ }^{1}$
}

Received: 13 February 2020 / Accepted: 8 June 2020 / Published online: 30 June 2020

(C) The Author(s) 2020

\begin{abstract}
Sustainability is a key factor in an automotive OEMs' business strategy. Vehicle electrification in particular has received increased attention, and major manufacturers have already undertaken significant investments in this area. However, in order to fully confront the sustainability challenge in the automotive industry, lightweight design in additional to alternative propulsion technologies is also required. Vehicle weight is closely correlated with fuel consumption and range for internal combustion and electrified vehicles, respectively, and therefore, weight reduction is a primary objective. Over the past decades, advanced steel and aluminium-forming technologies have seen considerable development, resulting in significant weight reduction of vehicle components. Hot stamping is one of the most established processes for advanced steel and aluminium alloys. The process offers low-forming loads and high formability as well as parts with high strength and minimal springback. However, the high temperatures of the formed materials over numerous cycles and the significant cooling required to ensure desirable component properties necessitate advanced tooling designs. Traditionally, casting and machining are used to manufacture tools; although in recent years, additive manufacturing has gained significant interest due to the design freedom offered. In this paper, a comprehensive review is performed for the state-of-the-art hot-forming tooling designs in addition to identifying the future direction of Additive Manufactured (AM) tools. Specifically, material properties of widely used tooling materials are first reviewed and selection criteria are proposed which can be used for the transition to AM tools. Moreover, key variables affecting the success of hot stamping, for example cooling rate of the component, are reviewed with the various approaches analysed by analytical and numerical techniques. Finally, a number of future directions for adopting additive manufacturing in the production of hot stamping tools are proposed, based on a thorough analysis of the literature.
\end{abstract}

Keywords Additive Manufacturing $\cdot$ Design for Additive Manufacturing $\cdot$ Hot stamping $\cdot$ Die design

\section{Introduction}

Globally, manufacturing is regarded as one of the primary sources of wealth, and yet, the large amount of energy used for industrial operations, in combination with the increasing demand for goods, causes significant environmental repercussions. Until recently, the performance of a production system has been evaluated by taking into consideration four main attributes as follows: cost, time, quality and flexibility [1]. However, global megatrends [2] such as climate change are

Liliang Wang

liliang.wang@imperial.ac.uk

1 Department of Mechanical Engineering, Imperial College London, Exhibition Road, London SW7 2AZ, UK

2 Department of Mechanical and Manufacturing Engineering, University of Cyprus, 1678 Nicosia, Cyprus moving the manufacturing community towards the consideration of sustainability. As a result, sustainability must be considered in all stages of the manufacturing decision-making process [3]. The automotive industry is a major sector adapting to this new framework, which consists of government-regulated emission standards such as Euro 6 for Europe or CAFE for the USA, or even more radical political rulings such as the UK's decision to ban all petrol and diesel vehicles by 2040 [4]. The answer of the automotive industry to this challenge is electrification, and major automotive OEMs have already announced plans for full electric or plug-in hybrid vehicles [5].

However, vehicle sustainability should not be addressed by focussing on electrification alone. Another key element in efficiency is lightweight design, which can reduce the environmental footprint of both internal combustion (IC) and electrified vehicles. Vehicle weight closely correlates with fuel consumption and range, for IC and electrified vehicles, 
respectively, and thus its reduction is effective regardless of vehicle propulsion technology. The objective of lightweight design is to minimise dead weight of a construction without impinging on function, safety or useful life [6].

Over the past decades, advanced steel manufacturing technologies have seen considerable development, resulting in the significant reduction of vehicle component weight through the use of advanced steel alloys, such as high-strength steel (HSS), advanced high-strength steel (AHSS) and ultra-highstrength steel (UHSS) [7]. In the automotive industry, ultrahigh-strength steels can be considered a relatively 'low cost' lightweight material option compared with aluminium alloys, and OEMs have extensive knowledge regarding their manufacturability. Moreover, their capability to absorb impact energy in a collision as well as their adequate formability and joining capability make steel alloys a popular choice with automotive manufacturers. On the other hand, aluminium has attracted significant attention due to an improved strength-to-weight ratio compared with steel and unique corrosion behaviour [8]. A characteristic example of the increased adoption of aluminium is in North American OEM vehicles, which has seen an increase of $27 \%$ between the years 2012 and 2015. The increase stems from an equal combination of higher vehicle production and increased aluminium content per vehicle (Ducker [9]). According to the literature [10], aluminium will comprise of more than $75 \%$ of pickup truck body parts, $24 \%$ of large sedans, $22 \%$ of SUVs and $18 \%$ of minivan body and closure components by 2025 .

Hot stamping is considered one of the main forming processes for manufacturing advanced steel and aluminium alloy sheet components $[11,12]$. The number of hot stamping parts is increasing in a BiW with most of them used in the crashrelated zones. These zones must resist intrusion and maintain their integrity. Numerous studies have been published regarding hot stamping of roof rail [13], door impact beam [14] or Bpillar inner $[15,16]$. On the other hand, cold forming is mainly used with mild steel which is mainly used for non-critical safety parts such as closures [17]. Hot stamping processes have increased complexity compared with cold stamping, as successive processes such as quenching are crucial to the control of cooling rate and subsequent post-form strength [18]. The cooling rate is determined largely by the quantity of thermal energy transferred from the deformed component to the tool cooling system.

Press tools are typically designed with internal cooling channels and manufactured by conventional machining processes such as drilling, in order to achieve the desirable cooling rates. A significant challenge to existing cooling channel production methods is that the channels are unable follow an equidistant profile to the tool surface, resulting in inconsistent quench rates throughout the component [19]. In addition, large press tools are manufactured by segmenting a single tool into multiple pieces, which are individually machined and subsequently assembled. Tool segmentation is also often required due to limitations of cooling channel drilling technologies [20].

To this end, additive manufacturing (AM) offers significant advantages, as opposed to conventional subtractive technologies [21]. These include the fabrication of complex geometries, material savings, design flexibility and reduced tooling costs [22]. The most evident realisation of these advantages has been in plastic injection moulding, where steel tools for final production, have been fabricated using additive techniques in several works [23-28]. However, the adoption of $\mathrm{AM}$ techniques for direct hot stamping tooling has seen limited progress.

The authors acknowledge the significant potential of the $\mathrm{AM}$ on the design and manufacture of hot stamping tooling. Thus, the aim of this article is to review currently available literature in the area that AM and hot stamping tooling intersect. Section 2 provides an overview of hot stamping and its process principles. Section 3 reviews recently published studies on Additively Manufactured hot stamping dies. Section 3.1 investigates design approaches of cooling systems for hot stamping dies and how these can be applied for AM, while in Section 3.2 simulation models are reviewed and suggestions are proposed for their use in AM. Then, Section 3.3 reviews the thermo-mechanical properties of wellestablished hot stamping tooling materials and identifies minimum threshold criteria that can be used for the transition to Additively Manufactured materials. Finally, summary and concluding remarks of the study are provided as well as the authors' outlook for AM in hot stamping tooling.

\section{Hot stamping of ultra-high-strength steels and aluminium alloys}

\subsection{Hot stamping of ultra-high-strength steels}

Hot stamping processes for ultra-high-strength steels currently exist in the following two main variants: direct and indirect hot stamping processes (Fig. 1). In a direct hot stamping process, the blank is heated in a furnace, transferred to the press and subsequently formed and quenched in the closed tool. An indirect hot stamping process is characterised by the use of a nearly complete cold pre-formed part which is subjected only to a quenching and calibration operation in the press after austenitisation [30].

A crucial requirement in the hot stamping of steels is the transformation of the material microstructure from austenite to martensite to achieve the desirable post-form mechanical properties. This can be achieved through careful thermal control at each process stage. During heating, the temperature must be above the re-crystallisation temperature in order for the microstructure to achieve austenisation. Moreover, the 
Fig. 1 Existing hot stamping technologies for UHSS. a Direct hot stamping, $\mathbf{b}$ indirect hot stamping [29]

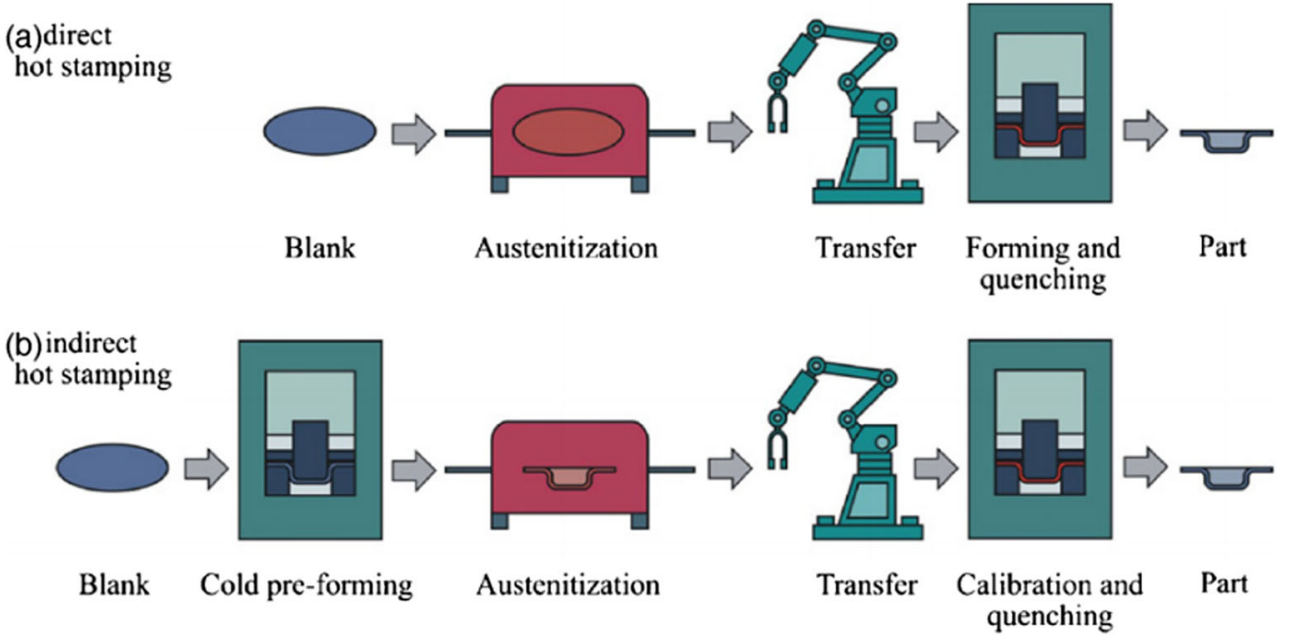

blank temperature must be homogeneous, which is a precondition for the desired fully martensitic transformation [31]. During the subsequent hot blank transfer operation to the forming tool, the temperature decreases rapidly due to heat loss to the surrounding environment. Lengthy transfer times may result in microstructural transformation to bainite and ferrite, and therefore, it is crucial to place the blank in the die at a temperature above $730{ }^{\circ} \mathrm{C}$. The final operation is to form the blank inside the die and simultaneously quench. The cold die acts as a heat sink to the hot blank during quenching, enabling the hot blanks microstructure to be transformed from austenite to martensite. However, this phase change is realised only when the cooling/quenching rate is above a critical value, which is alloy-dependent. If the cooling rate is below this value, the microstructure of the final part will consist of bainite or ferrite phases, which will affect the final mechanical properties. CCT diagrams are used to represent the types of phase changes that will occur in a material as it is cooled at different rates. In Fig. 2, the CCT diagram of $22 \mathrm{MnB} 5$ is shown. Studies regarding this material have concluded that the critical cooling rate to achieve a full martensite transformation is 30 ${ }^{\circ} \mathrm{C} / \mathrm{s}$ [33-36].

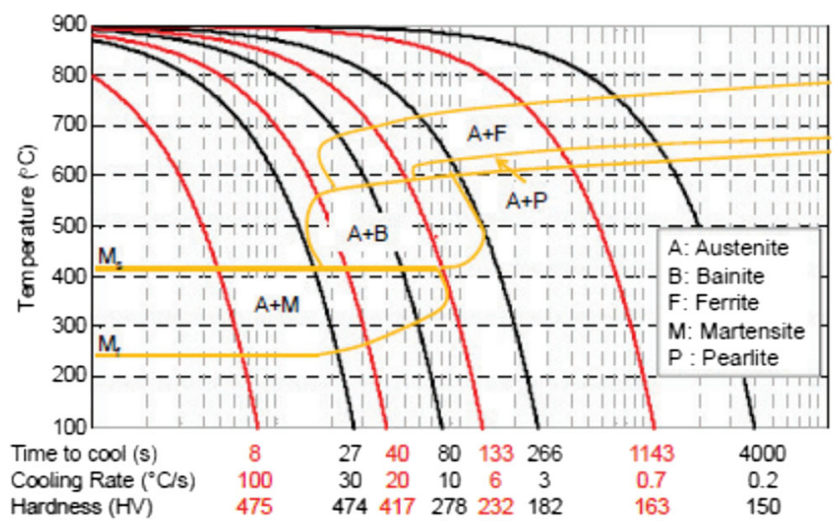

Fig. 2 CCT diagram of 22MnB5 [32]
Since the cooling of the blank occurs within the dies, hot stamping die design is critical to the cooling performance and directly affects productivity. It has been found that quenching time accounts for up to $30 \%$ of the total process cycle time [37].

\subsection{Hot stamping of high-strength aluminium alloys}

Conventional forming of aluminium alloys encounters the following two major issues: (i) the low formability of aluminium

(a)

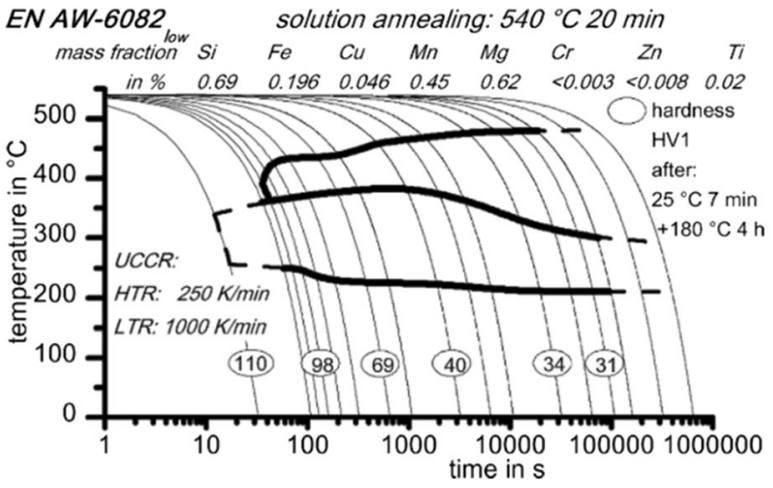

(b) EN AW-7075 linear cooling from: $480^{\circ} \mathrm{C} 15 \mathrm{~min}$

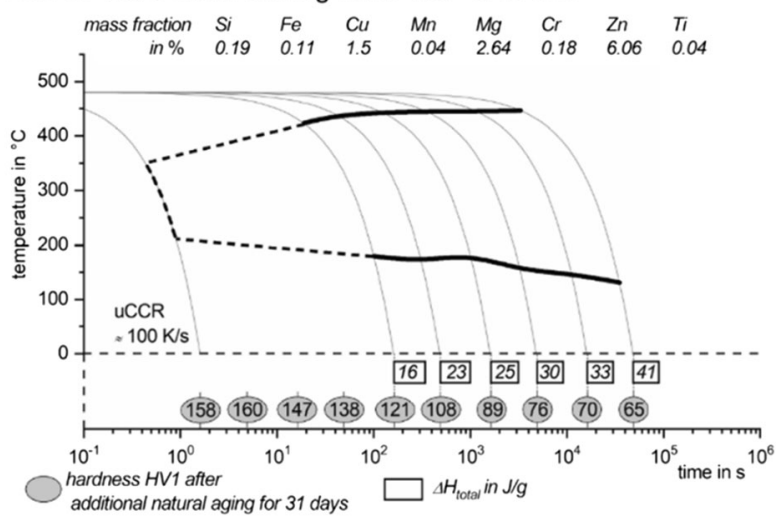

Fig. 3 CCP diagrams for a 6082 aluminium alloys [58] and b 7075 aluminium alloys [57]. 
alloys at room temperature which significantly limits their application to the forming of complex-shaped components [38] and (ii) the low stiffness of aluminium alloys at room temperature which causes high springback of the formed components [39]. Solution heat treatment, cold die forming and indie quenching (HFQ) was developed as a promising hot stamping technology to address these two issues [40-42]. During an HFQ forming process, an aluminium alloy blank is first heated to its solution heat treatment temperature (SHT) followed by a specific period of soaking, in order to fully dissolve alloying elements and/or precipitates into the material matrix, resulting in high formability of the aluminium alloy. After the heat treatment, the hot blank is transferred to a press machine and then stamped into the desired shape by forming tools at room temperature. Simultaneously, the hot blank is quenched at a sufficiently high-cooling rate to achieve a supersaturated solid solution state (SSSS). Consequently, precipitates are uniformly generated and distributed within the aluminium matrix during the subsequent artificial ageing, reaching high post-form strength of the formed component. Due to these pronounced benefits, HFQ was patented globally $[43,44]$ and commercialised for automotive applications [45].

In recent years, Fast light Alloy Stamping Technology (FAST) was developed and patented as a novel hot stamping process, not only increasing the formability of aluminium alloys and decreasing springback but also significantly reducing cycle time [46, 47]. During such a forming process, an aluminium alloy blank is heated to an elevated temperature at an ultra-fast heating rate, in order to enhance the ductility of the material while maintaining its microstructure. Subsequently, the hot blank is transferred to a press machine, and simultaneously deformed and quenched by cold forming tools at a high cooling rate. Due to minor changes to the microstructure, the artificial ageing period is dramatically reduced to achieve the desired post-form strength. The elimination of lengthy heating, soaking and ageing periods is beneficial to the reduction of cycle time. Furthermore, the processing parameters, such as temperature, heating rate, transfer time and cooling rate, could be customised to satisfy customer requirements for the post-form mechanical properties of the formed components [48-50].

Considering these advantages, hot stamping of aluminium alloys has been studied by numerous researchers, under the prism of identifying optimum processing windows to realise customer requirements. In the study by Harrison et al. [51], the transfer time of a hot blank from a furnace to a press machine was reduced and precisely controlled by using a robotic arm to ensure that a SSSS state for AA7075 could be achieved after quenching. The stamping speed and blank holding force were optimised to reduce wrinkling and/or fracture of anti-collision side beams made from AA6111, as stated in the study by Zhou et al. [52]. The application of lubricants is another efficient method to avoid crack formation in formed components [53,
54]. Additionally, some researchers have employed dedicated equipment in the hot stamping of aluminium alloys to realise desirable processing windows. For instance, a servo motor was applied in the study by Song et al. [55], to enable for a more uniform distribution of temperature and strain in AA7075 sheets. Resistance heating equipment was also employed by Maeno et al. [56] to shorten the heat treatment of aluminium alloys.

Despite the differences between these processing windows, all forming processes have the critical requirement of quenching the aluminium alloys within cold forming tools. By evaluating the continuous cooling precipitation (CCP) diagram of aluminium alloys, it can be found that the cooling curve intersects the regions where coarse precipices (e.g. $\beta$ and $\beta^{\prime}$ for 6 XXX alloy) are generated. This results in secondary particles being precipitated out and consuming alloying elements which would lead to a decrease in the post-form mechanical strength. Therefore, critical cooling rates for aluminium alloys must be achieved during quenching to avoid this phenomenon $[57,58]$. As a heat transfer medium, tools significantly affect the cooling rate of aluminium alloys, and therefore the selection of tool materials and designs is of great importance in order to achieve the critical cooling rate [53, 54].

It is well understood that hot stamping of both highstrength steels and aluminium alloys is a complex process that requires precise control of thermomechanical phenomena. However, while the majority of studies focus on the material properties of the final formed component, the significance of the applied tooling must also be emphasised [59].

\section{Additive manufacturing of hot stamping dies}

The manufacture of hot stamping dies with internal cooling channels is a challenging task due to limitations in conventional processes. Currently, there are three methods of manufacturing internal cooling channels for hot stamping dies [60] as shown in Fig. 3. The first is the conventional drilling method. This method, although most cost effective [61], has a profound disadvantage. Drilling can only produce straight line bores and cooling channels which are unable to maintain an equidistance from a complex 3D tool surface geometry. Consequently, "hot spots" are obtained which are essentially areas on a final component that have been cooled at different rates compared with the rest of the component and inherently exhibit varied mechanical properties. The second method involves the segmentation of the die into two parts; the shell and the core, with the cooling channels divided between them. Although this approach increases the design flexibility, it is associated with increased cost and material waste. Moreover, the sealing between the two parts is a significant challenge 
which contributes to its reduced popularity. The final method involves producing the die through casting and pre-fixing the cooling channels inside the casting mould. However, fixing the cooling channels is not a simple task, and there is the possibility of the cooling channels melting during the casting of the die. Moreover, casting a die necessitates additional postprocessing that it is not required by the other two methods. The manufacturing of hot stamping dies is typically associated with other research areas such as high performance cutting of hot work steels [62-64]. However, the review of such studies is outside the scope of this paper. Fig. 4

There are strong indications that AM can be a disruptive technology for hot stamping tools. The design flexibility offered can aid designers to realise concepts that are currently unachievable using conventional manufacturing processes. Moreover, in the authors' opinion, metal-forming tooling is the only area that can fully exploit the benefits of AM processes in the short term as high production volumes are not required for such applications. In the automotive industry, the manufacturing of a die usually takes 21 weeks [65], and therefore even with current deposition rates, AM technologies can be considered as a viable alternative. In this section, smallscale case studies are presented addressing the application of AM. Although there are several published studies regarding the application of AM to tooling, this work focuses specifically on studies addressing hot stamping and does not include results from other manufacturing sectors such as injection moulding.

Cortina et al. [66] investigated the design of conformal cooling ducts, which were additively manufactured on a CR7V-L hot work steel substrate and then post-processed with milling. AISI H13 and AISI 316L laser claddings were used as the filler material for the manufacture of the cooling channels (Fig. 5).

The mechanical as well as thermal performance of the specimen shown in Fig. 5 was evaluated, and it was concluded that laser cladding is a viable alternative manufacturing process. In Fig. 6, the thermal performance of the two cooling channels is shown and it can be observed that they are almost identical.

The authors subsequently transferred the proposed manufacturing approach to a complex geometry (Fig. 7) and their cooling effectiveness was compared with conventional manufacturing. The results showed that a more homogeneous temperature distribution could be achieved with AMed channels.

In addition, the study by Muller et al. [37] has also highlighted the benefits of additively manufacturing cooling channels. It was determined that the main benefit of complex cooling channels following the profile of the parts was the radically reduced quenching time during hot stamping processes, which accounts for $30 \%$ of the cycle time. The cooling system was redesigned through simulations, and the key input parameters were the compression force, workpiece temperature, coolant temperature, flow rate and internal surface roughness of the cooling channels. The resulting improvement in both the temperature gradient and temperature on the die's working surface was significant (Fig. 8).

The performances of the cooling systems were evaluated by simulating the temperature distribution on the final component. It is clear that the most critical area is in the die's deepest cavity, which conventional cooling channels could not reach due to manufacturing limitations in following the geometric profile of the part. The AMed cooling channels
Fig. 4 Different manufacturing methods for internal cooling channels (adapted from [60])

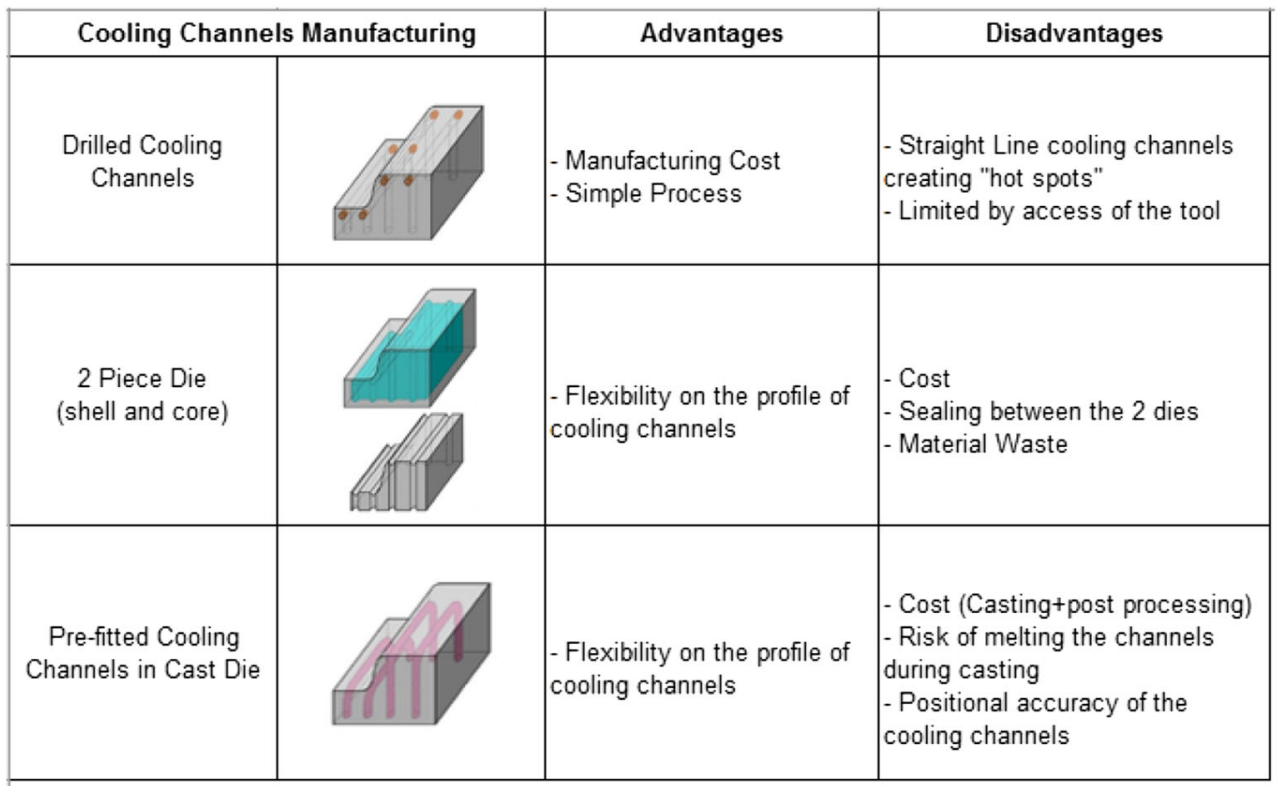


Fig. 5 a Initial CR7V-L substrate with one drilled channel and prepared machined surfaces for cladding. b Finished sample with one drilled and one additively manufactured cooling channel [66]
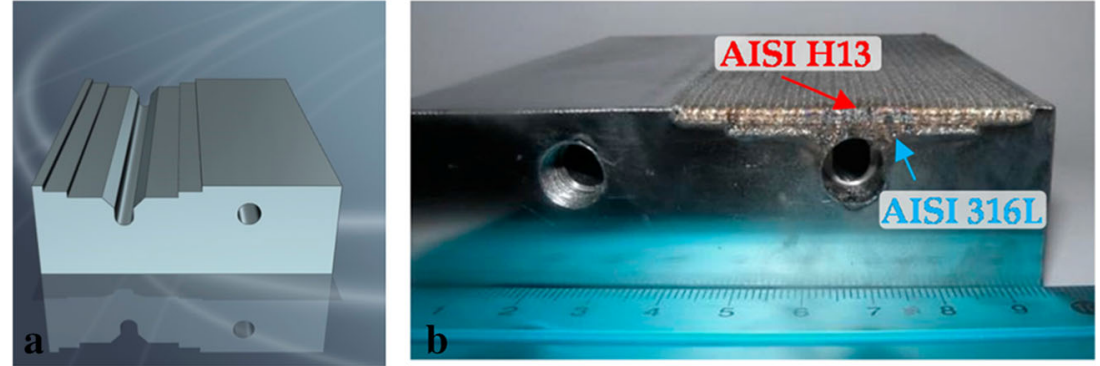

were able to achieve a temperature in this area that was almost $50 \%$ lower than with conventional cooling channels (Fig. 9).

In addition to simulation work, the authors conducted experimental work that verified that the additively manufactured tools reduced the quenching time by $50 \%$.

The studies of Cortina et al. [66] and Muller et al. [37] are the only studies that have investigated the potential of additive manufacturing for hot stamping processes of metallic parts. From a review of the literature, the majority of published papers have focused on the investigation of AM in injection moulding of plastic parts [23-28]. As the focus of this review is on AM for metal hot stamping, injection moulding studies are not taken into consideration due to the variations of thermal and mechanical loads.

\subsection{Design of cooling system for hot stamping dies}

Quenching is one of the main bottlenecks to the overall hot stamping cycle time [67] with Muller et al. [37] estimating this process to account for $30 \%$ of the total production process. Quenching is achieved through a medium which flows through the cooling system and acts as a heat sink extracting heat from the blank. It is clear that a cooling system with tangential cooling channels to the working surface of the die and to each other would be ideal from a thermodynamic point of view. However, this would deteriorate the mechanical performance of the die and would compromise its structural integrity. Moreover, the diameter of a cooling channel plays a significant role in the thermal performance of the die. A greater volume of cooling medium can flow through a large diameter compared with a smaller one. However, there is a limit on the cooling channel diameter as significant removal of material can compromise die integrity.

Therefore, it is clear that the design of a cooling system for a hot stamping die is a multi-objective optimisation task. Ideally, conformal cooling design is preferred; however, due to manufacturing constraints, they may be prohibitively expensive. Hence, straight circular drilled cooling channels are the most practical choice in industry thus far.

\subsubsection{Design for additive manufacturing of hot stamping die cooling systems}

The almost infinite design flexibility that AM technologies offer compared with existing die manufacturing technologies enables the manufacturing of optimised cooling channels for hot stamping dies. However, due to the additive nature of these processes, there are several design constraints that the
Fig. 6 Measurements from a thermal camera (left, coolant is off; right, coolant is on) [66]

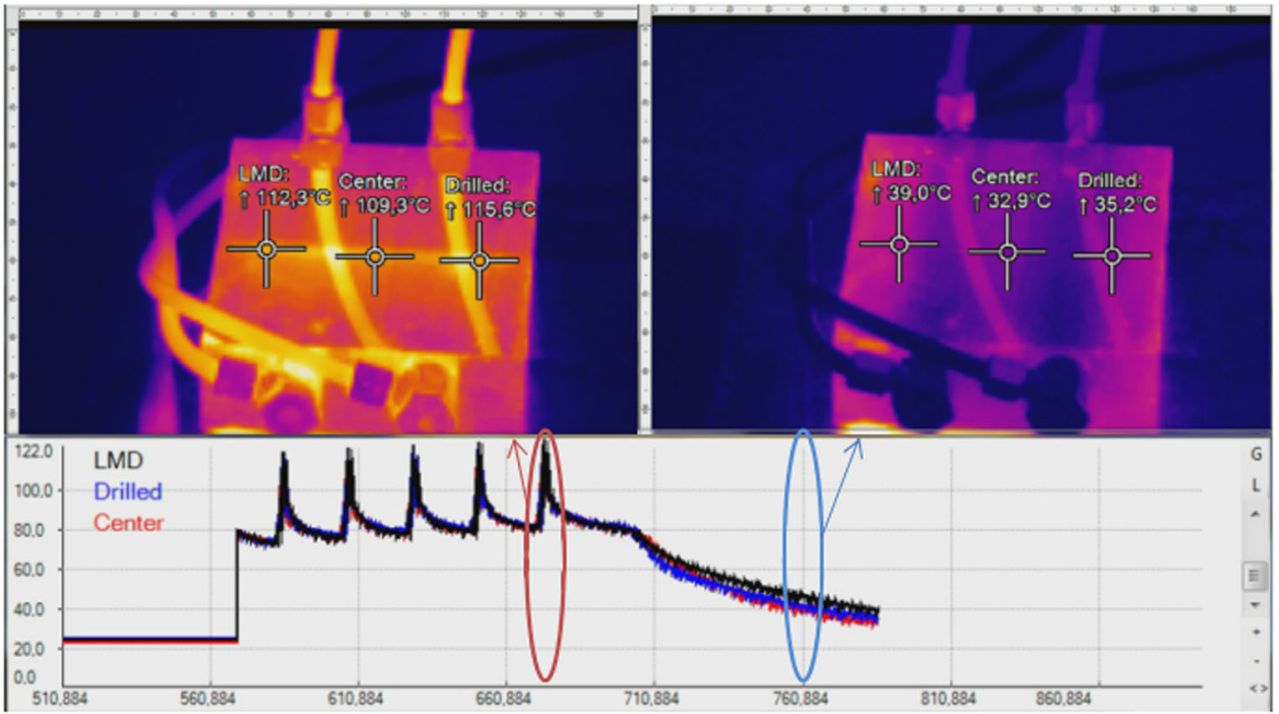



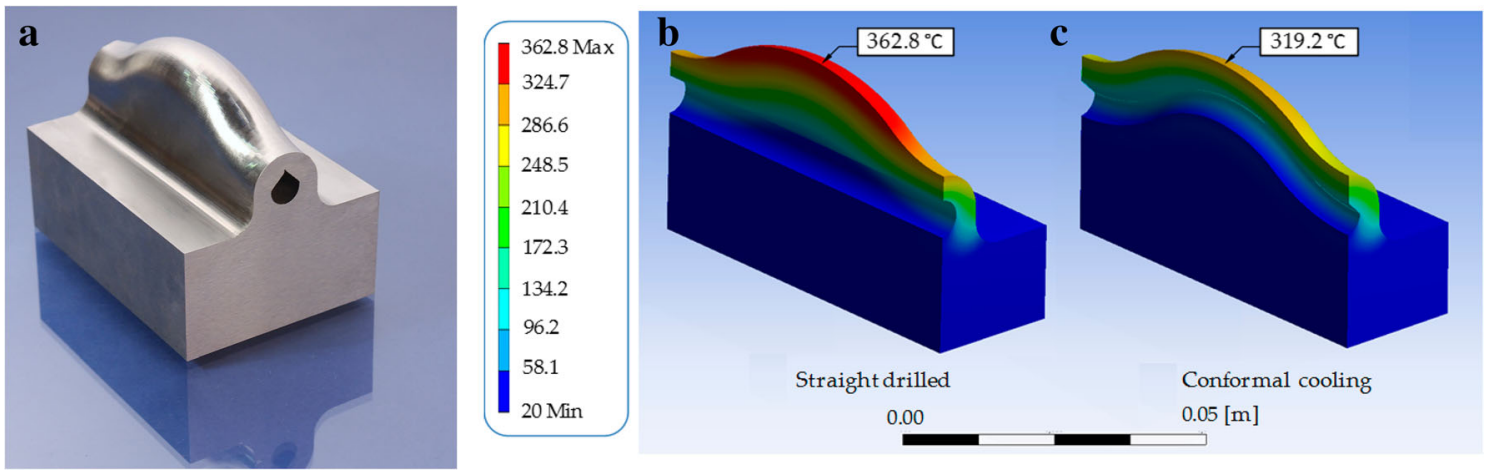

Fig. 7 a Complex geometry with conformal cooling channels. b Temperature distribution with conformal cooling channels. c Temperature distribution with conventional channels [66]

designer must consider. For instance, components which are designed with overhanging features may require sacrificial supports to build them successfully. These supports increase build time, consume extra powder material and require additional post-processing for their removal. Therefore, in the context of AM hot stamping die cooling systems, a design for AM (DfAM) approach is critical for the production, performance and cost effectiveness of additive manufacture.

Lim et al. [68] has provided calculations for the average temperature of the tool surface by using an analytical model based on the energy balance principle and a specific cycle time. Based on the average temperature, the diameter of the cooling channels was determined and a recommended range of cooling diameters for different blank thicknesses was provided as shown in Table 1.

It is observed that for blank thicknesses up to $2 \mathrm{~mm}$, which is the typical blank thickness used in hot stamping, a cooling channel of $8-10 \mathrm{~mm}$ diameter is recommended. Mazur et al. [69] investigated the AM manufacturability of conformal cooling channels and concluded that a circular profile section channel of 2-8 $\mathrm{mm}$ would be compromised in cylindrical accuracy by $6 \%$ due to build errors where arc sections approach the horizontal. To overcome this issue, several studies proposed a design for cooling channels with easy to build supportive internal lattice structures [24, 70, 71]. The concept was evaluated and the results showed that indeed the proposed design reduces cooling time. The reason is that the lattice structures were found to increase heat transfer due to increased interfacial surface areas and fluid vorticity. Although the results are positive, the proposed approach has been experimentally validated only in the case of a straight cooling channel [71] (Fig. 10). In the case of conformal cooling channels where the centre line of a cooling channel is complex, the internal lattices may severely affect the coolant flow and consequently decrease the quenching effect.

Another approach to overcome the issue of circular accuracy of the cooling channels is to use self-supported cross sections such as diamond shaped or teardrop shaped. However, the designer should always consider the orientation of the part inside the chamber as this is the main parameter that characterises whether a structure is self-supported or not. For instance, a teardrop shaped-cooling channel is self-supported if the circular section is oriented towards the base plate (Fig. 11) but is not when rotated 180 degrees.

Orientation can impact other aspects such as surface quality of the part or build time and any effort to develop a holistic optimisation strategy will give contradictory results. For instance, high volume of support structures will be needed if a die is horizontally placed. However, in this case the build time will be reduced since the number of layers will be fewer compared with when the part is placed vertically. Usually, proposed methods for orientation optimisation are focussing on

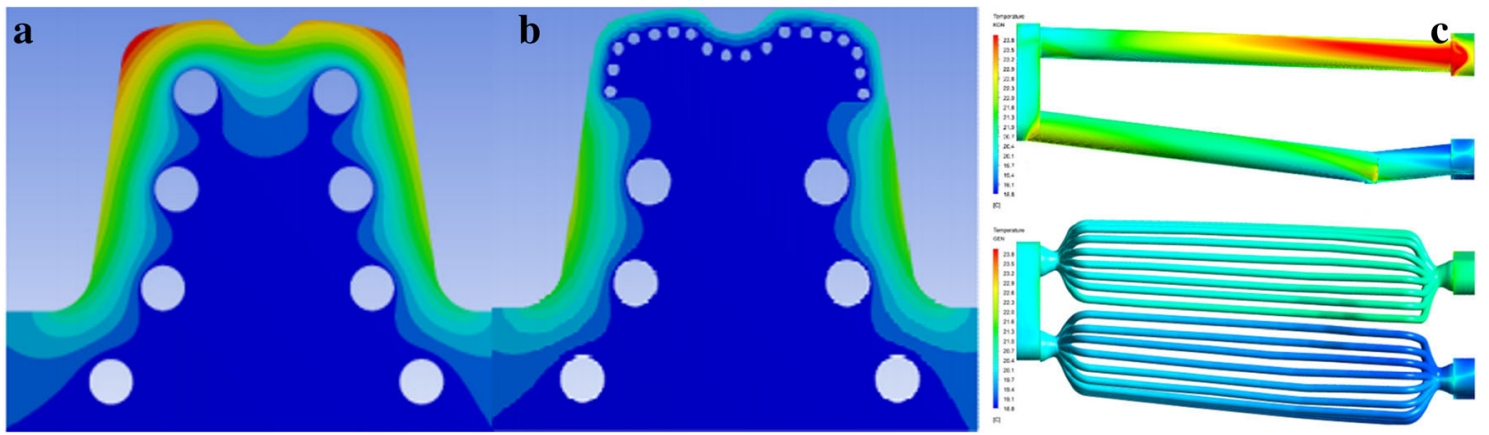

Fig. 8 a Conventional drilled cooling channels (max temperature in the tool $191{ }^{\circ} \mathrm{C}$ ), b optimized cooling channels (max temperature $81{ }^{\circ} \mathrm{C}$ ), $\mathbf{c}$ comparison of the temperature gradient in the conventional and optimized cooling system [37] 
Fig. 9 Temperature distribution in the final part for a conventional cooling channels (temperature in the deepest cavity $335^{\circ} \mathrm{C}$ ) and b AMed cooling channels (temperature in the deepest cavity $\left.177^{\circ} \mathrm{C}\right)[37]$

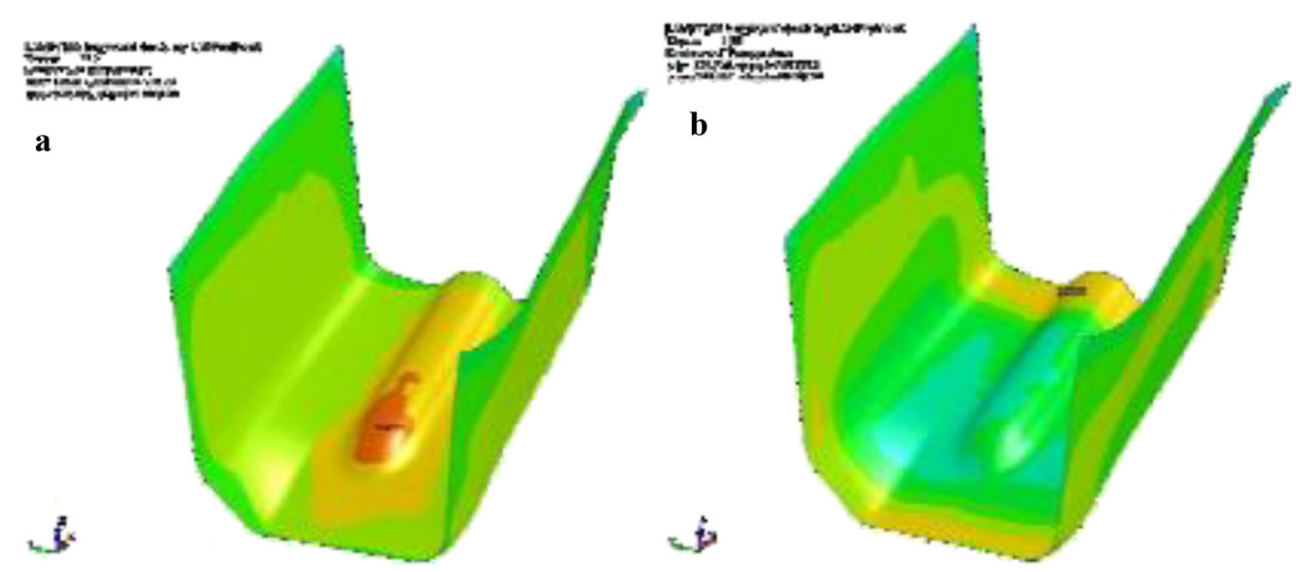

a specific objective. There are part orientation optimisation methods for minimising the surface roughness of the final part $[72,73]$, increasing mechanical properties such as strength to a specific direction $[74,75]$, and reducing support structures or even minimizing build time [73, 76-78]. In the case of hot stamping dies, the key objective should be the manufacturability of cooling channels without support structures. Other aspects such as surface roughness are not crucial as an additively manufactured die will be post-processed. Post-processing is necessary for AM components as the typical surface roughness values for SLM are 10-15 $\mu \mathrm{m}$, whereas for EBM are 20$35 \mu \mathrm{m}$ [79], which are in excess of the $8 \mu \mathrm{m}$ required by industry for hot stamping dies. However, a potential postprocessing of the cooling channels might not be possible due to difficulty in accessing the required locations. Moreover, an additional challenge, which derives from the limited build volumes of current additive manufacturing machines, is that a hot stamping die for industrial applications cannot be printed in one part. Therefore, the designer must develop a segmentation strategy in order to utilise as much of the available printing volume as possible.

\subsection{Simulation approaches for the design of hot stamping die cooling systems}

A short quenching time is dependent, alongside other parameters, on the design of the cooling system of the die. There are three main design parameters that need to be identified for the design of a die's cooling system; the distance of the cooling channel from the working surface of the die (dsp), the distance

Table 1 Cooling channel diameter guideline based on blank thickness

\begin{tabular}{ll}
\hline Blank thickness, $\mathrm{t},(\mathrm{mm})$ & Cooling channel diameter, $\mathrm{d},(\mathrm{mm})$ \\
\hline $\mathrm{t} \leq 2$ & $8 \leq \mathrm{d} \leq 10$ \\
$2 \leq \mathrm{t} \leq 4$ & $10 \leq \mathrm{d} \leq 12$ \\
$4 \leq \mathrm{t} \leq 6$ & $12 \leq \mathrm{d} \leq 14$ \\
\hline
\end{tabular}

between two neighbouring cooling channels (dpp) and the diameter of the cooling channel (D) [80, 81].

Both analytical and computational simulation models have been used in the literature for the design of a hot stamping die. The majority of analytical models use the energy balance principle as well as heat transfer theory and can provide a rapid calculation although of reduced accuracy for $d_{\mathrm{sp}}, d_{\mathrm{pp}}$ and $D$. For increased accuracy, many researchers use finite element analysis (FEA) methods to optimally select the design variables for a hot stamping die cooling system. A summary of key modelling methodologies and respective studies are summarised in Table 2.

The main issue of the aforementioned models is that they have been developed for hot stamping dies manufactured with conventional processes and materials. Computational and analytical models need to be revised to take into account some inherent characteristics of AM processes.

AM-produced components encounter a complex cyclic thermal history consisting of directional heat extraction, repeated melting and rapid solidification, which creates anisotropic and heterogeneous microstructures that differ from metallic parts manufactured via conventional methods. Moreover, AM defects such as pores and lack of fusion layers

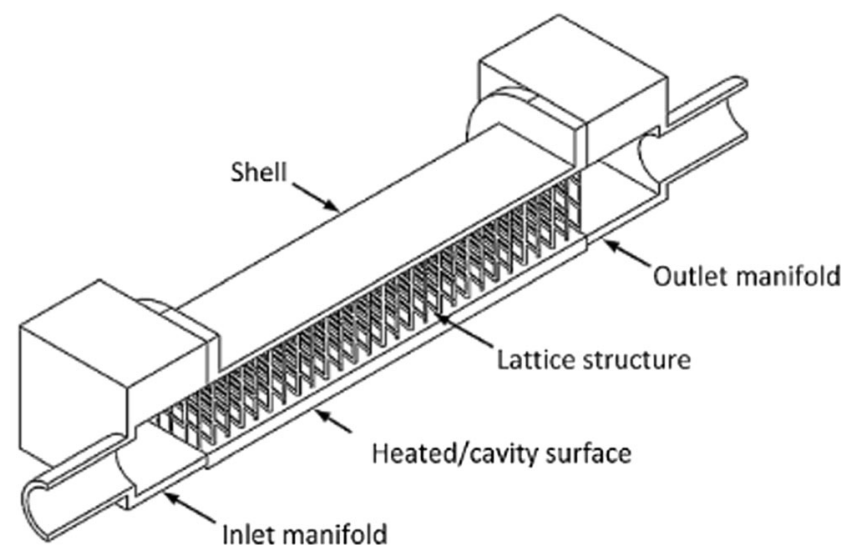

Fig. 10 Proposed concept of additively manufactured cooling channels [71] 
Fig. 11 Effect of build direction on printability of a design feature

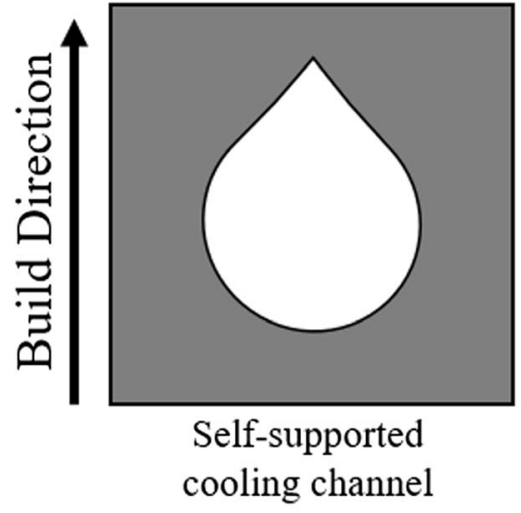

would induce anisotropic and heterogeneous properties such as thermal conductivity to the final part. Furthermore, the cooling channels in an additively manufactured die cannot be circular due to the overhang issue discussed previously. Thus, analytical models should be revisited and adjusted accordingly.

Finally, with the design flexibility that AM processes offer, hot stamping dies with improved thermal performance can be produced by integrating lattice structures to the main body of the die. Lattice structures can be used to insulate die sections in proximity to the cooling channels of the die, reducing thermal mass and thus improving quenching efficiency. Several researchers have investigated the effect of lattice structures on the thermal conductivity of hot stamping dies. Cheng et al. [88] developed an analytical model which predicts the thermal conductivity of a BCC lattice core sandwich structure. The model was validated experimentally although applying analytical methods to predict heat dissipation within a die with lattice structures is impractical and becomes unfeasible as the complexity of lattice topology increases. Therefore, the FEA
Table 2 Key modelling studies on hot stamping cooling systems

\begin{tabular}{|c|c|c|}
\hline Authors & Modelling methodology & Key remarks \\
\hline$[82]$ & $\begin{array}{l}\text { Analytical model considering: } \\
\text { i. Thermal conductivity of die } \\
\text { material } \\
\text { ii. Velocity and temperature of } \\
\text { cooling medium }\end{array}$ & $\begin{array}{l}\text { The study concluded that shorter cooling times can be attained } \\
\text { by placing the cooling channels closer to each other and } \\
\text { closer to the die working surface }\end{array}$ \\
\hline $\begin{array}{l}{[81]} \\
{[80]}\end{array}$ & $\begin{array}{l}\text { Analytical model considering } \\
\text { stamping force }\end{array}$ & $\begin{array}{l}\text { Most influential factor on cooling effectiveness is } d_{\mathrm{sp}} \text {, followed } \\
\text { by } d_{\mathrm{pp}} \text { and } D\end{array}$ \\
\hline [83] & $\begin{array}{l}\text { Effect of water velocity in the } \\
\text { channel on the die temperature }\end{array}$ & $\begin{array}{l}\text { As the water velocity in a cooling system increased, the } \\
\text { temperature of the die rapidly decreased because of the } \\
\text { turbulent flow state. However, there is a limit to this effect, } \\
\text { where a velocity in excess of } 3.5 \mathrm{~m} / \mathrm{s} \text { causes no significant } \\
\text { effect on the die temperature }\end{array}$ \\
\hline [84] & $\begin{array}{l}\text { Analytical model considering only } \\
\text { heat transfer phenomena }\end{array}$ & Equations for calculation of $D$ and $d_{\mathrm{sp}}$ \\
\hline$[85]$ & FEA method & $\begin{array}{l}\text { The dimensions of the flume affect the water velocity and } \\
\text { consequently the flow uniformity. The relationship between } \\
\text { the flow field and flume width is that the wider the flume, } \\
\text { the better the flow uniformity in the cooling channels. On } \\
\text { the other hand, the flume height and flow field relationship } \\
\text { are not straightforward and follow a quadratic curve with the } \\
\text { maximum flow uniformity being achieved at a specific } \\
\text { flume height }\end{array}$ \\
\hline$[86]$ & $\begin{array}{l}\text { FEA method coupled with } \\
\text { evolutionary algorithm }\end{array}$ & $\begin{array}{l}\text { In some cases, cooling channels with smaller diameters can be } \\
\text { more effective than larger ones because they can be } \\
\text { positioned closer to the stamping surface without } \\
\text { compromising the integrity of the tooling }\end{array}$ \\
\hline$[87]$ & FEA method & $\begin{array}{l}\text { Use of segmented FEA models which reflect the geometric } \\
\text { features of the component. The proposed method reduces } \\
\text { computational time by } 92.6 \%\end{array}$ \\
\hline
\end{tabular}


analysis method is utilised in order to increase modelling accuracy. In the numerical analysis of parts with lattice structures, two different approaches can be distinguished, namely the micro-scale and the macro-scale approach. In the first approach, the exact lattice structure's geometry is modelled. However, this approach has an impact on the computational cost of the analysis, making it challenging even for modern computers, since the geometry is complex. On the other hand, as the lattice geometry is periodic, each cell can be modelled as a volume of a homogenous material resulting in a macroscale analysis and therefore reducing computational cost. The new homogenous material must have mechanical properties that will give the same response as the lattice cell. These properties are called effective material properties and can be either isotropic or orthotropic, depending on the lattice cell topology and dimensional parameters. Finding these properties requires the use of a technique known as "homogenization" which has been applied to other areas successfully [89]. Conclusively, the existing models, both analytical and computational, can act as a basis for the development of cooling systems. However, the models must be revised to acknowledge the anisotropic nature of AMed materials and be enriched by taking into account the new design features, such as cellular structures which can be manufactured by AM.

\subsubsection{Topology optimisation}

The unique capabilities of AM technologies allow innovative design approaches that challenge traditional guidelines of several major industries including the hot stamping tooling sector. Among these approaches, topology optimisation (TO) (Fig. 12) offers the greatest design flexibility, as it allows for material distribution in terms of physics requirements, offering the potential to create novel and complex parts with high performance and reducing material cost. TO generates a freeform geometry which is usually optimised against a specific objective, for example stiffness. However, the objectives of TO can be more than non-linear optimisation, which gives the optimum combination of two performance criteria such as thermal and mechanical. The concept of thermomechanical topology optimisation has been successfully applied in injection moulding and electronics. In the case of injection moulding, results have shown a reduction of cooling time by $70 \%$ without compromising the structural integrity of the mould [91]. In the case of hot stamping, there are limited research studies that investigate the benefits of thermomechanical topology optimisation. Another use of TO can be the design of overhang-free components for AM. A simple way to achieve the overhang-free design is through post-processing of the optimised geometry. For instance, Leary et al. [92] added materials to the topology optimisation resulting in the removal of overhang-free violations, which is effective even though the optimisation achieved by the TO process is compromised. A more structured approach was proposed by [93] in which the structural boundaries of the topology optimised geometry are measured and the support-required overhang segments are penalised.

TO can be extremely useful in hot stamping die design as it can generate a geometry which quenches the blank optimally and simultaneously generates overhang free geometries. Another important benefit is that topology-optimised dies require less material to be printed than fully solid ones. As a result, printing time can be reduced. However, to the authors' knowledge there are no available studies applying TO to hot stamping die design. It would be useful at this point to highlight that the thermal criterion for hot stamping dies should derive from the blank quenching rate rather than the temperature profile of the die. The reason is that the required critical cooling rate differs depending on material and can range from $30 \mathrm{~K} / \mathrm{s}$ for boron steel to up to $100 \mathrm{~K} / \mathrm{s}$ for AA7075-T6.

\subsection{Material properties for additively manufactured hot stamping dies}

Bulk materials for hot stamping dies require a unique combination of properties. They must exhibit high tensile strength, hardness and toughness values as well as good corrosion resistance. Additionally, the die material must exhibit a low thermal expansion coefficient and high thermal conductivity. It is common for the die material to be selected depending on the specific part to be formed. For instance, a die material of particularly high thermal conductivity is preferable when hot stamping relatively large part geometry, of relatively thick gauge, but of simple complexity and limited forming depth. On the other hand, a die material of high hardness is preferable when hot stamping complex part geometry with large forming depth, which generates high friction against the tools. Naganathan and Penter [94] outlined the most important bulk
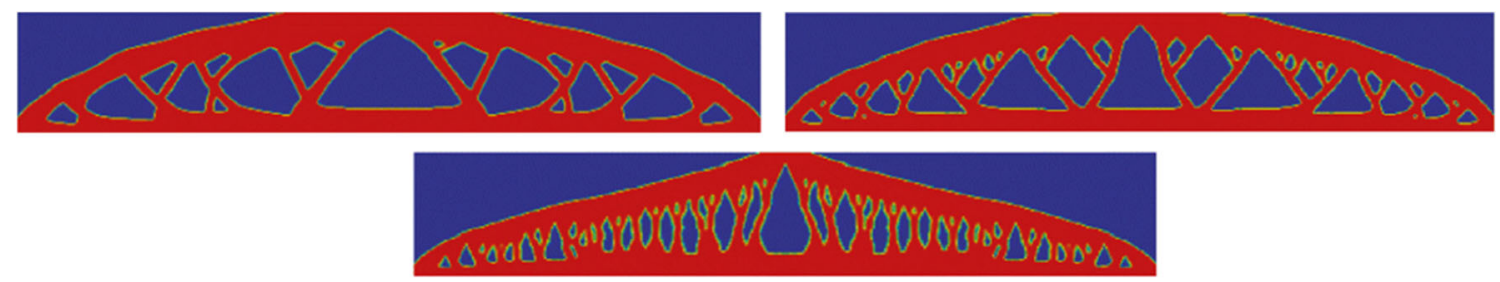

Fig. 12 Topology optimised geometries with various self-supporting angles (a $26.6 \mathrm{deg}$, b $45 \mathrm{deg}$, c $63.4 \mathrm{deg}$ ) Gaynor and Guest, [90] 
material properties for a hot stamping die, which are strength, hardness, impact toughness and thermal conductivity. Moreover, hot stamping is a process with cyclic thermal profile and since the aforementioned properties are temperaturedependent, the die must perform sufficiently in the operating temperature range. For example, UHSS stamping die temperatures may reach $300-400{ }^{\circ} \mathrm{C}$ [95], whereas for aluminium stamping, the die can reach up to $180{ }^{\circ} \mathrm{C}$ [96]. Temperaturedependent values of tensile strength, hardness, impact toughness and thermal conductivity of commonly used die materials are presented in Table 3. The empty cells reflect the lack of published data for material properties of hot work tool steels at elevated temperatures.

In the literature, there are no clear material selection criteria for hot stamping dies, with most studies focussing on the properties of the final components manufactured by hot stamping instead. The study by Ye et al. [109] has addressed many aspects of material selection, although the study is limited in that thermal conductivity is not considered an "index" for hot stamping die material selection.

In Fig. 13, the critical bulk material properties, as have been outlined, are graphically mapped for well-established hot worked steels. Commercially, these grades of hot work steels can be found with slight variations in mechanical properties due to different heat treatment strategies. As can be seen from

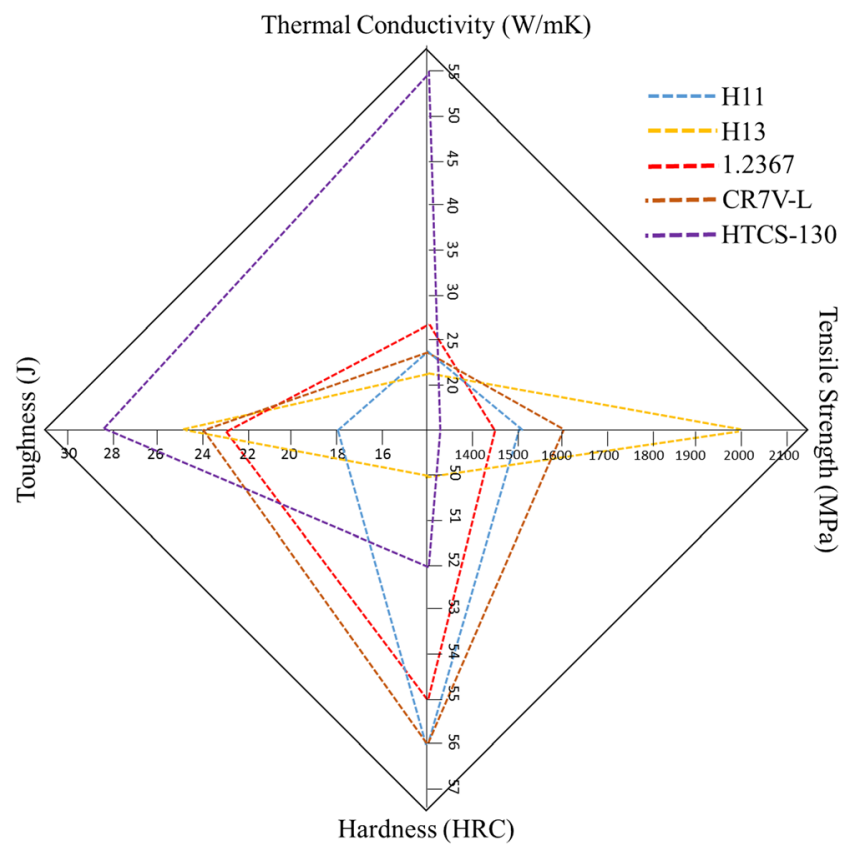

Fig. 13 Performance review of established materials for hot stamping (at $\left.25^{\circ} \mathrm{C}\right)$

Fig. 13, there is no singular material that demonstrates excellent performance for every material property. However, a material with minimum $18 \mathrm{~J}$ (Charpy $\mathrm{V}$ notch test) of impact

Table 3 Tensile strength, hardness and toughness values as a function of temperature of hot work tool steels

\begin{tabular}{|c|c|c|c|c|c|c|c|c|c|c|}
\hline \multirow[t]{2}{*}{ Material KPI } & \multirow[t]{2}{*}{ Steel Grade } & \multicolumn{8}{|c|}{ Operating temperature } & \multirow[t]{2}{*}{ Reference } \\
\hline & & $25^{\circ} \mathrm{C}$ & $100^{\circ} \mathrm{C}$ & $200^{\circ} \mathrm{C}$ & $300^{\circ} \mathrm{C}$ & $400^{\circ} \mathrm{C}$ & $500^{\circ} \mathrm{C}$ & $600^{\circ} \mathrm{C}$ & $700^{\circ} \mathrm{C}$ & \\
\hline \multirow{5}{*}{$\begin{array}{l}\text { Tensile Strength } \\
\text { (MPa) }\end{array}$} & H11 & 1505 & - & - & - & 1187 & 1035 & - & - & {$[97]$} \\
\hline & H13 & 1990 & - & 1480 & - & 1360 & 1050 & - & 500 & [98] \\
\hline & 1.2367 & 1457 & - & - & 1264 & 1184 & 985 & - & - & [99] \\
\hline & CR7V-L & 1600 & - & 1400 & 1350 & 1200 & 1150 & 800 & - & {$[100]$} \\
\hline & HTCS-130 & 1314 & - & - & - & 1200 & - & - & - & {$[101]$} \\
\hline \multirow{5}{*}{$\begin{array}{l}\text { Hardness } \\
\text { (HRC) }\end{array}$} & H11 & 56 & 52 & 48 & 45 & 42 & 38 & 35 & - & {$[102]$} \\
\hline & H13 & 50 & 46 & 45 & 43 & 41 & 37 & 30 & - & [98] \\
\hline & 1.2367 & 55 & - & 54 & 52 & 51 & 46 & 38 & - & [103] \\
\hline & CR7V-L & 56 & - & - & - & - & - & - & - & [100] \\
\hline & HTCS-130 & 50 & - & - & - & - & - & - & - & [104] \\
\hline \multirow{5}{*}{$\begin{array}{l}\text { Toughness } \\
\text { (J) }\end{array}$} & H11 & 18 & - & - & - & - & - & - & - & [102] \\
\hline & H13 & 25 & 28 & 36 & 40 & 42 & 43 & 41 & - & [97] [98] \\
\hline & 1.2367 & 23 & - & - & - & - & - & - & - & (P.[97]) \\
\hline & CR7V-L & 56 & - & - & - & - & - & - & - & {$[100]$} \\
\hline & HTCS-130 & 28.5 & - & - & - & - & - & 47 & - & [105] \\
\hline \multirow{5}{*}{$\begin{array}{l}\text { Thermal Conductivity } \\
(\mathrm{W} / \mathrm{mK})\end{array}$} & H11 & - & 26.8 & - & 27 & 27.3 & - & 29.3 & - & [106] \\
\hline & H13 & 22.7 & 25.5 & 26.3 & 26.2 & 26.7 & 28.0 & 29.1 & 27.3 & [107] [98] \\
\hline & 1.2367 & 27.0 & 28.0 & 30.0 & 29.0 & 28.0 & 27.0 & - & - & [108] \\
\hline & CR7V-L & 24.5 & 26.2 & 26.9 & 27.0 & 27.2 & 28.2 & 29.6 & 31.0 & [107] \\
\hline & HTCS-130 & 50.8 & 54.6 & 54.2 & 51.5 & 49.2 & 48.0 & 47.1 & 43.5 & [107] \\
\hline
\end{tabular}


toughness, $50 \mathrm{HRC}$ hardness, $1300 \mathrm{MPa}$ tensile strength and $22 \mathrm{~W} / \mathrm{mK}$ could provide adequate performance for hot stamping operations.

There are two main categories of AM processes: Directed Energy Deposition (DED) and Powder Bed Fusion (PBF) [110]. The main difference between these two families of processes is that DED typically relies upon the feeding of powder or wire into the melt path, while in PBF, the powder is already spread, within a chamber, before an energy source, either laser or electron beam, selectively fuses regions of powder in order to form a functional component. Usually, powder or wire feedstock DED processes exhibit higher deposition rates than PBF processes since the deposition and fusion are conducted simultaneously. Moreover, DED processes can be used to manufacture larger parts than PBF since the fabrication is not constrained by chamber's dimensions. However, PBF processes can produce complex components with better dimensional accuracy and surface finish [111]. As far as hot stamping tooling is concerned, the PBF processes are the best choice, since the existing industrial studies on similar applications of injection moulds have shown very good performance [112]. Moreover, according to Roland Berger [113], PBF is the most mature metal printing technology and still the strongest selling with machine sales rising steadily over the last ten years. Thus, rest of Section 3.3 reviews solely the material properties of SLMed materials which are suitable for hot stamping applications although all the remarks from previous sections are transferable to any other AM processes.

In Table 4, an overview of SLM powder materials from a range of suppliers is presented, and it can be seen that for the same material, large variations exist in their properties. The data presented were derived from specific build strategies such as a specific build orientation, layer thickness, laser speed and laser power, and therefore, the maximum values for the material properties from each supplier are presented. The first observation that can be made is that there is a significant absence of impact toughness and thermal conductivity data, whereas values for tensile strength and hardness are widely available. As a result, the evaluation of each material against the four critical material properties for hot stamping tooling cannot be conducted. However, there are materials that can be easily excluded as an alternative choice for hot stamping tooling applications. For instance, all the aluminium alloys, although demonstrating acceptable thermal conductivity values, do not meet either the tensile strength requirement, which is $1300 \mathrm{MPa}$, nor the hardness criterion (50 HRC). The same applies to most stainless steel materials. Therefore, the only viable alternatives are maraging steels, CL50WS, EOS Stainless Steel CX and H13. These all meet both the tensile strength and hardness requirements and are close to the defined $22 \mathrm{~W} / \mathrm{mK}$ threshold for thermal conductivity. The reason for not excluding these materials as potential alternatives, despite not meeting the thermal conductivity requirements, is that there have been limited investigations into whether the same materials can meet all criteria by using an alternative build strategy.

Finally, it should be mentioned that there are some studies that have investigated the performance of an additively manufactured tool built from powder produced by wrought material suppliers. Valls et al. [132] used high thermal conductivity steel powder from Rovalma, one of the suppliers of high thermal conductivity steels (HTCS). Although the material properties of this powder were not presented, the authors managed to produce a final AM tool component with an even hardness distribution. However, currently, there is a lack of published data, and future research should focus on investigating HTCS as well. "Conventional" hot stamping tooling material manufacturers have acknowledged the benefits of AM in hot stamping and will eventually develop their powder capability.

\subsubsection{Effect of process parameters on selective laser-melted material properties}

Selective Laser Melting (SLM) [133] has over 50 different process parameters that can impact the quality of the final part, creating a significant challenge in understanding process physics and developing an effective build strategy [134] (Table 5).

Variations in the process parameters can influence not only the microstructure of the final components but may lead to the generation of defects [135]. Different values for laser power and speed parameters have been shown to cause a considerable change to the microstructure leading to anisotropic behaviour [136] [137, 138]. Another common defect is porosity, which can affect almost every aspect of the performance of the final part [135]. Porosity is generally related to pores inside the starting powder that are transmitted to the final deposition. Furthermore, it can be caused by the lack of fusion of the powder material, due to insufficient energy being delivered by the laser source to the powder particles. AM processes are therefore sensitive to process parameter variations. Several key studies on process development of AMed materials are presented in Table 6 .

However, as the AM process is being assessed for hot stamping tooling applications, an evaluation of the effect of AM process parameters on the tensile strength, hardness, toughness and thermal conductivity is required. Table 7 summarises all the key studies on process development of AMed H13, MS1 and MS300. The reported results in most cases are in line with the data reported by industrial suppliers (Table 4). It has been observed that heat treatment after the processing of components delivers higher tensile strength and hardness but lower impact toughness values. Moreover, it has been identified that a minimum laser volumetric energy density of 60 $\mathrm{J} / \mathrm{mm}^{3}$ is suitable for achieving densities higher than $99 \%$ on 
Table 4 Overview of commercially available SLM materials

\begin{tabular}{|c|c|c|c|c|c|c|}
\hline Powder material & Supplier & Tensile strength & Hardness & Impact toughness & Thermal conductivity & Reference \\
\hline AlSi10Mg & EOS & $460 \mathrm{MPa}$ & $120 \mathrm{HBW}$ & - & $120 \mathrm{~W} / \mathrm{mK}$ & [114] \\
\hline AlSi10Mg & SLM Solutions & $428 \mathrm{MPa}$ & $122 \mathrm{HV}$ & - & - & [115] \\
\hline AlSi10Mg & Renishaw & $366 \mathrm{MPa}$ & $113 \mathrm{HV}$ & - & $190 \mathrm{~W} / \mathrm{mK}$ & {$[116]$} \\
\hline Cobalt fhrome MP1 & EOS & $1350 \mathrm{MPa}$ & $45 \mathrm{HRC}$ & - & $13 \mathrm{~W} / \mathrm{mK}$ & {$[117]$} \\
\hline $\mathrm{H} 13$ & SLM Solutions & $1888 \mathrm{MPa}$ & - & - & - & {$[115]$} \\
\hline Steel CL50WS & Concept Laser & $1969 \mathrm{MPa}$ & $52 \mathrm{HRC}$ & - & $20 \mathrm{~W} / \mathrm{mK}$ & [118] \\
\hline Maraging steel & Renishaw & $1952 \mathrm{MPa}$ & $561 \mathrm{HV}$ & - & $14.2 \mathrm{WmK}$ & [119] \\
\hline Maraging steel 1.2709 & SLM Solutions & $1784 \mathrm{MPa}$ & 373 HV[10] & - & - & [115] \\
\hline Maraging steel MS1 & EOS & $1930 \mathrm{MPa}$ & $56 \mathrm{HRC}$ & $15 \mathrm{~J}$ & $20 \mathrm{~W} / \mathrm{mK}$ & {$[120]$} \\
\hline Nickel alloy CL100NB & Concept Laser & $1047 \mathrm{MPa}$ & - & - & $12 \mathrm{~W} / \mathrm{mK}$ & {$[121]$} \\
\hline Nickel alloy HX & EOS & $820 \mathrm{MPa}$ & - & - & - & {$[122]$} \\
\hline Nickel alloy HX & SLM Solutions & $800 \mathrm{MPa}$ & $248 \mathrm{HV}$ & - & - & [115] \\
\hline Nickel alloy IN625 & EOS & $827 \mathrm{MPa}$ & $30 \mathrm{HRC}$ & - & - & [123] \\
\hline Nickel alloy IN625 & SLM Solutions & $961 \mathrm{MPa}$ & $285 \mathrm{HV}$ & - & - & {$[115]$} \\
\hline Nickel alloy IN625 & Renishaw & $1055 \mathrm{MPa}$ & $332 \mathrm{HV}$ & - & $10.7 \mathrm{~W} / \mathrm{mK}$ & {$[124]$} \\
\hline Nickel alloy IN718 & EOS & $1241 \mathrm{MPa}$ & 47HRC & - & - & {$[125]$} \\
\hline Nickel alloy IN718 & SLM Solutions & $1034 \mathrm{MPa}$ & $293 \mathrm{HV}$ & - & - & [115] \\
\hline Nickel alloy IN718 & Renishaw & $1379 \mathrm{MPa}$ & $456 \mathrm{HV}$ & & $12 \mathrm{~W} / \mathrm{mK}$ & {$[126]$} \\
\hline Stainless steel $316 \mathrm{~L}$ & SLM Solutions & $633 \mathrm{MPa}$ & $209 \mathrm{HV}$ & - & - & [115] \\
\hline Stainless steel $316 \mathrm{~L}$ & Renishaw & $624 \mathrm{MPa}$ & $208 \mathrm{HV}$ & - & $16.2 \mathrm{~W} / \mathrm{mK}$ & {$[127]$} \\
\hline Stainless steel CL20ES & Concept Laser & $640 \mathrm{MPa}$ & $20 \mathrm{HRC}$ & - & $15 \mathrm{~W} / \mathrm{mK}$ & {$[128]$} \\
\hline Stainless steel CX & EOS & $1760 \mathrm{MPa}$ & 51HRC & - & - & [129] \\
\hline Titanium alloy Ti6A14V & SLM Solutions & $1301 \mathrm{MPa}$ & $380 \mathrm{HV}$ & - & - & {$[115]$} \\
\hline Titanium alloy Ti6Al4V & Renishaw & $1085 \mathrm{MPa}$ & $372 \mathrm{HV}$ & - & $8 \mathrm{~W} / \mathrm{mK}$ & {$[130]$} \\
\hline Titanium alloy CL TI41 & Concept Laser & $1106 \mathrm{MPa}$ & - & - & $7 \mathrm{~W} / \mathrm{mK}$ & {$[131]$} \\
\hline
\end{tabular}

both maraging steel and H13. However, there are no available data regarding thermal conductivity which makes their assessment against hot stamping applications difficult but promising. Therefore, research efforts should focus towards this direction. Moreover, another demonstration on the limited adoption of AM in hot stamping is the lack of interfacial heat transfer coefficient (IHTC) data. IHTC between a hot blank and cold tools is an important thermophysical parameter in hot stamping processes that determines the cooling rate and consequently the post-form mechanical strength of formed components.

\section{Conclusion and Outlook}

The aim of this paper was to provide a review and conclusions on the application of Additive Manufacturing to the design and production of hot stamping dies. AM, a technology that enables almost infinite design freedom, can revolutionize the design and manufacturing of hot stamping dies. Design methodologies such as topology optimisation can deliver dies with minimum use of material without compromising either their structural integrity or thermal performance. Moreover, the manufacture of bespoke cellular geometries such as lattice structures can selectively substitute solid areas within the die's body and enhance its thermal performance. In summary, the key aspects which a designer must consider during the development of an AMed hot stamping die are presented in Fig. 14. However, there are significant gaps in the research which must be addressed to enable the successful adoption of AM in the hot stamping tooling industry. These efforts should focus on three main areas.

The first area is the characterisation of AMed materials which are suitable for hot stamping die manufacture. Conventionally manufactured and widely established hot tool steels demonstrate properties of at least $1300 \mathrm{MPa}$ tensile strength, $50 \mathrm{HRC}$ hardness, $18 \mathrm{~J}$ of impact toughness and 22 $\mathrm{W} / \mathrm{mK}$ of thermal conductivity. Any AMed materials should demonstrate at least these properties in order to be considered a reliable alternative.

AM refers to a family of processes such as DED and PBF processes or even binder jetting. The authors recommend that PBF processes and specifically SLM be a suitable process for hot stamping die manufacture, because it 


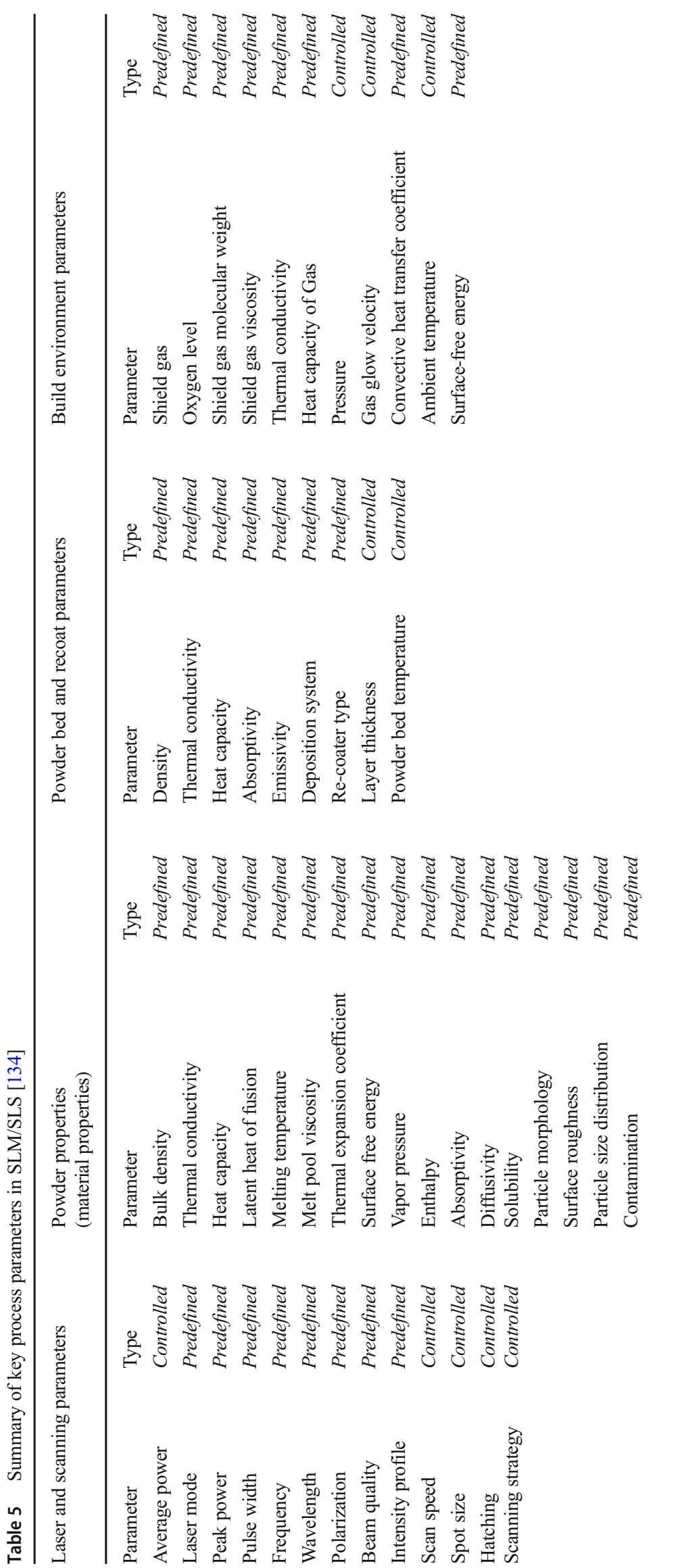


Table 6 Key studies on process development of SLM

\begin{tabular}{|c|c|c|c|}
\hline Authors & Scope & Material & Key remarks \\
\hline $\begin{array}{l}([139 \\
140] \\
{[141]}\end{array}$ & $\begin{array}{l}\text { Laser average power and scanning } \\
\text { speed }\end{array}$ & $\begin{array}{l}\text { Ti6Al4V, } \\
\text { Mg-9\%Al, SS } \\
\quad 316 \mathrm{~L}\end{array}$ & $\begin{array}{l}\text { Process maps between laser speed and power indicates the available process } \\
\text { window for each powder. }\end{array}$ \\
\hline$[142]$ & Laser scanning hatch angle & SS 304 & $\begin{array}{l}\text { Changing hatch angle and an increasing interval number }(\mathrm{N}) \text { also aids in limiting } \\
\text { grain growth in a single direction, minimizing anisotropy in mechanical } \\
\text { properties and residual stress, as well as increasing tensile strength }\end{array}$ \\
\hline $\begin{array}{l}{[143]} \\
\quad[144] \\
{[145]}\end{array}$ & $\begin{array}{l}\text { Effect of powder deposition system } \\
\text { on part quality }\end{array}$ & Regardless & $\begin{array}{l}\text { Powder deposition system guarantees uniform layer thickness which leads to a } \\
\text { homogeneous material solidification } \\
\text { Increased blade velocities lead to dynamic powder post-flow and decreased mean } \\
\text { layer thicknesses } \\
\text { Increase of recoating time influences thermal gradient along the building axis. A } \\
\text { higher recoating time allows more time for the part to cool down between layers }\end{array}$ \\
\hline [146] & $\begin{array}{l}\text { Layer thickness impact on material } \\
\text { properties }\end{array}$ & SS $316 \mathrm{~L}$ & $\begin{array}{l}\text { Layer thickness has a significant effect on microhardness. A thicker layer reduces } \\
\text { hardness and tensile strength }\end{array}$ \\
\hline [147] & $\begin{array}{l}\text { Powder bed temperature effect on } \\
\text { material properties and quality }\end{array}$ & SS $316 \mathrm{~L}$ & $\begin{array}{l}\text { Increase of powder bed temperature increases part density and improves } \\
\text { dimensional accuracy }\end{array}$ \\
\hline $\begin{array}{l}([148 \\
149] \\
{[150]}\end{array}$ & Gas flow, Velocity and pressure & $\begin{array}{l}\text { Al-12Si, } \\
\text { SS } 316 \text { L }\end{array}$ & $\begin{array}{l}\text { For Al-12Si powder, the type of gas used did not significantly affect the part density } \\
\text { or hardness, with a maximum density of } 98 \% \\
316 \text { L SS samples fabricated under Ar, N2 and their mixtures with H2 exhibit near } \\
\text { full density with values above } 99 \% \\
\text { Maximum melt pool temperature should not exceed the vaporization temperature of } \\
\text { the powder and vaporization temperature changes with the gas pressure in the } \\
\text { building chamber }\end{array}$ \\
\hline
\end{tabular}

is a fastest growing AM process in the industry, leading to significant know-how already in place in the supply chain, combined with continuously developed powder materials. Moreover, SLM demonstrates greater dimensional accuracy and surface roughness than DED or other PBF processes as well as the ability to manufacture complex geometries such as lattice structures and conformal cooling channels. Both industrial suppliers and research institutes have conducted material characterisation studies to a variety of SLMed materials, ranging from AlSi10Mg to Ti6A14V. Grades of maraging steel or H13 can be considered a potential alternative to conventional tooling materials as they meet most of the defined thresholds, although significant research efforts are required to study the thermal conductivity of these grades. Moreover, AM is a delicate process with a high-level of anisotropy, and the quality of the final component can be affected by over 50 process parameters. In addition, conclusions can be drawn from the currently available literature. Laser Volumetric Energy Density (VED) between $60 \mathrm{~J} / \mathrm{mm}^{3}$ and $100 \mathrm{~J} / \mathrm{mm}^{3}$ is required to deliver a fully dense microstructure. Since VED is a function of laser power, scanning speed, layer thickness and laser overlap, the aforementioned range of VED can be achieved by a combination of these parameters. For all the investigated studies, the hatch angle was set at 67 degrees. Moreover, it is highlighted that heat treatment after printing significantly increases the hardness of the final component. The optimal heat treatment strategy for maraging steel is a heating cycle of 6 hours at $480^{\circ} \mathrm{C}$. Additionally, in the case of $\mathrm{H} 13$, it was found that parts printed with a powder bed temperature of $400^{\circ} \mathrm{C}$ demonstrate a homogeneous microstructure and improved mechanical properties compared with parts produced with or without lower powder bed temperature. Thus far, published data has demonstrated the potential for H13 and maraging steel, although further investigations are required to understand the effect of each process parameter on the quality of a functional AMed die. For instance, there are insufficient available data on temperature-dependent material properties. This aspect must be further investigated since the operating temperature of hot stamping significantly affects the performance of an AM die.

The second area of study is the development of simulation models for the internal cooling system of hot stamping dies. It is shown that cooling systems with conformal channels eliminate hot spots on the dies, providing uniform properties on the final components, as well as increased quenching efficiency and consequently decreased process cycle time. Manufacturing of conformal cooling channels is limited by conventional manufacturing processes due to cost implications, although AM technologies can produce these types of channels without any additional cost. The existing models, which drive the design of the cooling systems, address areas related to the diameter of a cooling channel, its distance from the die working surface and the 
Table 7 Key studies on process development of SLMed materials suitable for hot stamping applications

\begin{tabular}{|c|c|c|c|}
\hline Authors & Scope & Material & Key Remarks \\
\hline$[151]$ & $\begin{array}{l}\text { Microstructure and mechanical properties } \\
\text { characterisation }\end{array}$ & $\begin{array}{l}\text { Maraging } \\
\text { steel } \\
18 \mathrm{Ni}-300\end{array}$ & $\begin{array}{l}\text { Maximum hardness } 58 \mathrm{HRC} \\
\text { Maximum UTS } 2216 \mathrm{MPa} \\
\text { Charpy impact } 5 \mathrm{~J} \text { with heat treatment }\end{array}$ \\
\hline$[152]$ & $\begin{array}{l}\text { Microstructure and mechanical properties } \\
\text { characterisation }\end{array}$ & H13 & $\begin{array}{l}\text { Ferritic/martensitic steels can be robustly processed by SLM by inducing } \\
\text { retained austenite within the microstructures improving the mechanical } \\
\text { properties of such steels without the necessity of employing a subsequent } \\
\text { heat treatment }\end{array}$ \\
\hline$[153]$ & $\begin{array}{l}\text { Experimental investigation on process } \\
\text { windows of maraging steel } 18 \mathrm{Ni} 300\end{array}$ & $\begin{array}{l}\text { Maraging } \\
\text { steel } \\
18 \mathrm{Ni} 300\end{array}$ & $\begin{array}{l}\text { Laser power higher than } 90 \mathrm{~W} \text { and laser scanning speed lower than } 220 \mathrm{~mm} / \mathrm{s} \\
\text { can deliver parts with densities greater than } 99 \% \text {. Reported ultimate tensile } \\
\text { strength (UTS) and hardness values are } 1085-1192 \mathrm{MPa} \text { and } 30-35 \mathrm{HRC} \text {, } \\
\text { respectively. In this study, the specimens were not heat treated }\end{array}$ \\
\hline [154] & Effect of preheating on the SLM of H13 & H13 & $\begin{array}{l}\text { Preheating temperatures of } 400^{\circ} \mathrm{C} \text { during SLM deliver parts with better } \\
\text { mechanical properties than parts produced without or with lower preheating } \\
\left(200{ }^{\circ} \mathrm{C}\right) \text {. SLMed H13 UTS }(1965 \mathrm{MPa}) \text { is similar to conventionally } \\
\text { produced H13 and the hardness is significantly higher }\left(667 \mathrm{HV}_{0.5}\right)\end{array}$ \\
\hline$[155]$ & Hardness investigation & H13 & $\begin{array}{l}\text { Tempered directly after SLM, H13 specimens exhibit similar hardness level } \\
\text { with conventional heat treated bulk H13 material. However, the peak in } \\
\text { secondary hardness of SLM H13 specimens is shifted to higher } \\
\text { temperatures and this phenomenon should be further investigated }\end{array}$ \\
\hline$[156]$ & Applicability investigation of MS18Ni300 & $\begin{array}{l}\text { Maraging } \\
\text { steel } \\
18 \mathrm{Ni} 300\end{array}$ & $\begin{array}{l}\text { Heat treatment is necessary for SLM of MS18Ni300 in order to achieve } \\
\text { optimum harndess }(650 \mathrm{HV}) \text { and UTS }(2100 \mathrm{MPa})\end{array}$ \\
\hline [157] & $\begin{array}{l}\text { Experimental investigation on process } \\
\text { windows of MS300 including anisotropy } \\
\text { effect }\end{array}$ & $\begin{array}{l}\text { Maraging } \\
\text { steel } 300\end{array}$ & $\begin{array}{l}\text { Heat treatments were crucial to improve the properties of SLM-produced MS } \\
\text { and eliminating mechanical anisotropy. Density wise, the optimum laser } \\
\text { energy density is found at } 67 \mathrm{~J} / \mathrm{mm}^{3} \text {. The highest UTS, HRC and charpy } \\
\text { impact energy values were } 2014 \mathrm{MPa}, 54.6 \mathrm{HRC} \text { and } 15.5 \mathrm{~J} \text {, respectively. }\end{array}$ \\
\hline$[158]$ & $\begin{array}{l}\text { Experimental investigation on process } \\
\text { windows of } \mathrm{H} 13\end{array}$ & H13 & $\begin{array}{l}\text { Fully dense parts can be achieved with and without preheating with a } \\
\text { minimum energy density of } 60 \mathrm{~J} / \mathrm{mm}^{3} \text {. Achieved hardness by SLM is } \\
\text { comparable to a conventionally produced } \mathrm{H} 13 \text { tool steel }\end{array}$ \\
\hline [159] & Fatigue characterisation of SLMed MS1 & $\begin{array}{l}\text { Maraging } \\
\text { steel MS1 }\end{array}$ & $\begin{array}{l}\text { Fatigue life of SLMed MS1 is identified at } 581 \mathrm{MPa} \text {, corresponding to } 28 \% \text { of } \\
\text { the UTS }\end{array}$ \\
\hline $\begin{array}{l}\text { (Wang } \\
\text { et al., } \\
\text { 2019) }\end{array}$ & High temperature properties of SLMed H13 & H13 & $\begin{array}{l}\text { Effects of tempering temperature and holding time of the softening resistance } \\
\text { treatment were systematicaly studied. SLMed H13 exhibits higher hardness } \\
\text { than wrought counterparts }(650 \mathrm{HV} \text { compared to } 600 \mathrm{HV}) \text {. Moreover, } \\
\text { SLMed specimens showed a hardness of } 475 \mathrm{HV} \text { when tempering for } 12 \\
\text { hours at } 600 \mathrm{C} \text {, which was closed to the wrought parts after } 4 \text { hours } \\
\text { treatment }(496 \mathrm{HV})\end{array}$ \\
\hline$[160]$ & $\begin{array}{l}\text { Process parameters effect of MS300 on } \\
\text { residual stresses and porosity }\end{array}$ & MS300 & $\begin{array}{l}\text { Strong relationship between process parameters and porosity, residual stresses } \\
\text { and associated distortions. Increasing layer thickness results in a decline in } \\
\text { residual stresses and distortion (less than } 0.6 \mathrm{~mm} \text { ) but can increase porosity } \\
\text { by up to 5\% }\end{array}$ \\
\hline
\end{tabular}

distance between two consecutive cooling channels. However, most of the proposed models must be adjusted under the prism of AM. In the case of analytical models, thermal conductivity and tensile strength of the die material should be adjusted to the "AM equivalent" properties as their values are heavily dependent on the manufacturing strategy. Moreover, the cross section of AMed cooling channels in mostly not circular. As a result, the volume of the cooling medium flowing through the channel can be affected leading to different cooling results. On the other hand, the main challenge in computational models, apart from the development of material cards for AM materials, is the discretisation of highly complex geometries that can be generated by applying a Design for AM (DfAM) approach. Lattice structures are design features that can be highly utilised in the design of a hot stamping dies, but their relatively small dimensions compared with the whole die can increase the computational cost during a FEA. Segmented models and homogenisation techniques can help to direct efficient simulation models.

Finally, the third area of proposed work refers to the development of Design for Additive Manufacturing (DfAM) rules for hot stamping tooling applications. One of the most critical issues in this area is the design 
Fig. 14 Critical aspects of highperformance stamping tool design for elevated temperatures

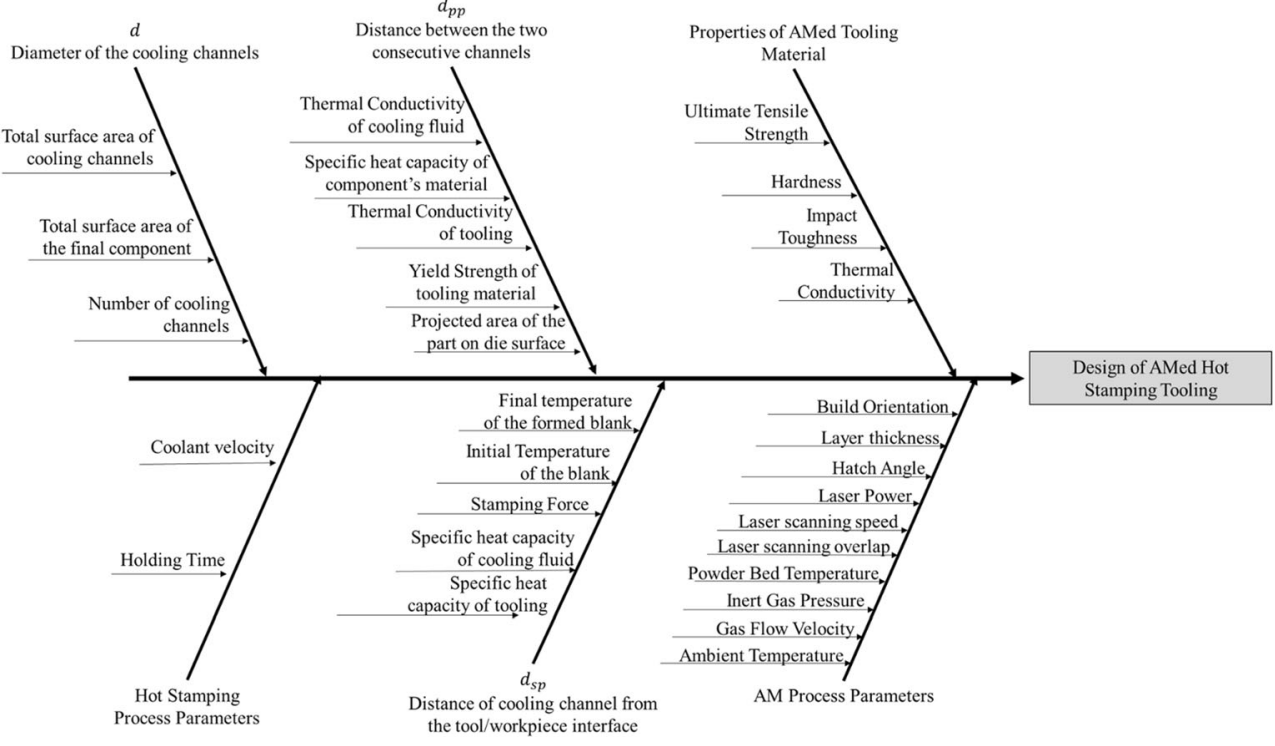

of self-supported design features to eliminate support structures, especially in internal cavities of the die such as cooling channels. DfAM rules can be combined with topology optimisation algorithms in order to generate geometries both without supports and be thermomechanically optimised.

Open Access This article is licensed under a Creative Commons Attribution 4.0 International License, which permits use, sharing, adaptation, distribution and reproduction in any medium or format, as long as you give appropriate credit to the original author(s) and the source, provide a link to the Creative Commons licence, and indicate if changes were made. The images or other third party material in this article are included in the article's Creative Commons licence, unless indicated otherwise in a credit line to the material. If material is not included in the article's Creative Commons licence and your intended use is not permitted by statutory regulation or exceeds the permitted use, you will need to obtain permission directly from the copyright holder. To view a copy of this licence, visit http://creativecommons.org/licenses/by/4.0/.

\section{References}

1. Chryssolouris G (1991) Manufacturing systems: theory and practice, 2nd ed, Mechanical engineering series. Springer-Verlag, New York. https://doi.org/10.1007/0-387-28431-1

2. European Environment Agency (2015) European environment state and outlook 2015: Assessment of global megatrends. Eur Environ. https://doi.org/10.2800/45773

3. Salonitis K, Ball P (2013) Energy efficient manufacturing from machine tools to manufacturing systems. Procedia CIRP 7:634 639. https://doi.org/10.1016/j.procir.2013.06.045

4. Department for Environment Food \& Rural Affairs, Department for Transport (2017) UK plan for tackling roadside nitrogen dioxide concentrations: An overview.

5. Ford (2017) CEO Strategic Update [WWW Document]. URL http://shareholder.ford.com/ /media/Files/F/Ford-IR-V2/events-
and-presentations/2017/10-03-2017/Slides-Ford-CEO-StrategicUpdate-Oct-3-2017 f.pdf (accessed 10.16.17).

6. Neugebauer R, Altan T, Geiger M, Kleiner M, Sterzing A (2006) Sheet metal forming at elevated temperatures. CIRP Ann - Manuf Technol 55:793-816. https://doi.org/10.1016/j.cirp.2006.10.008

7. Ghassemieh E (2011) New trends and sevelopments in automotive industry, new trends and developments in automotive industry. InTech. https://doi.org/10.5772/1821

8. European Aluminium (2019) Road Transport Report [WWW Document]. URL https://www.european-aluminium.eu/aboutaluminium/aluminium-in-use/automotive-and-transport/ (accessed 5.16.19).

9. Ducker Worldwide (2016) Aluminum Content in Cars.

10. Ducker Worldwide (2017) Unprecedented Growth Expected for Automotive Aluminum as Multi-Material Vehicles Ascend [WWW Document]. URL http://www.drivealuminum.org/newsreleases/unprecedented-growth-expected-for-automotivealuminum-as-multi-material-vehicles-ascend-new-survey-ofautomakers-says/ (accessed 10.16.17).

11. Ismail A, Mohamed MS (2016) Review on sheet metal forming process of aluminium alloys, in: 17th International Conference on Applied Mechanics and Mechanical Engineering. pp. 19-21.

12. Taylor T, Clough A (2018) Critical review of automotive hotstamped sheet steel from an industrial perspective. Mater Sci Technol 34:809-861. https://doi.org/10.1080/02670836.2018. 1425239

13. Hall JN, Fekete JR (2017) Steels for auto bodies: a general overview, automotive steels: Design, Metallurgy. Processing and Applications Elsevier Ltd. https://doi.org/10.1016/B978-0-08100638-2.00002-X

14. Li MF, Chiang TS, Tseng JH, Tsai CN (2014) Hot stamping of door impact beam. Procedia Eng 81:1786-1791. https://doi.org/ 10.1016/j.proeng.2014.10.233

15. Harrison NR, Luckey SG (2014) Hot stamping of a B-pillar outer from high strength aluminum sheet AA7075. SAE Int J Mater Manuf 7:567-573. https://doi.org/10.4271/2014-01-0981

16. Perez-santiago R, Billur E, Ademaj A, Sarmiento C (2013) Hot stamping a b-pillar with tailored properties: experiments and preliminary simulation results, in: Int. Hot Stamping Conferences. Lulea, Sweden, pp. 83-90.

17. Reed J (2015) advanced high-strength steel technologies in the 2015 Ford Edge. Gt. Des. steel, Livonia MI 
18. Bruschi, S., Ghiotti, A., 2018. Advanced forming technologies learn more about hot stamping process hot stamping process.

19. Lin T, Song HW, Zhang SH, Cheng M, Liu WJ (2014) Cooling systems design in hot stamping tools by a thermal-fluidmechanical coupled approach. Adv Mech Eng 2014:545727. https://doi.org/10.1155/2014/545727

20. Xavier LF, Elangovan D (2013) Effective parameters for improving deep hole drilling process by conventional method - a review. Int J Eng Res Technol:2

21. Mellor S, Hao L, Zhang D (2014) Additive manufacturing: a framework for implementation. Int J Prod Econ 149:194-201. https://doi.org/10.1016/j.ijpe.2013.07.008

22. Ngo TD, Kashani A, Imbalzano G, Nguyen KTQ, Hui D (2018) Additive manufacturing (3D printing): A review of materials, methods, applications and challenges. Compos Part B Eng 143: 172-196. https://doi.org/10.1016/j.compositesb.2018.02.012

23. Armillotta A, Baraggi R, Fasoli S (2014) SLM tooling for die casting with conformal cooling channels. Int J Adv Manuf Technol 71:573-583. https://doi.org/10.1007/s00170-013-5523-7

24. Au KM, Yu KM (2007) A scaffolding architecture for conformal cooling design in rapid plastic injection moulding. Int $\mathrm{J}$ Adv Manuf Technol 34:496-515. https://doi.org/10.1007/s00170006-0628-x

25. Ferreira JC, Mateus A (2003) Studies of rapid soft tooling with conformal cooling channels for plastic injection moulding. J Mater Process Technol 142:508-516. https://doi.org/10.1016/S09240136(03)00650-2

26. Jahan SA, El-Mounayri H (2016) Optimal conformal cooling channels in 3D printed dies for plastic injection molding. Procedia Manuf 5:888-900. https://doi.org/10.1016/j.promfg. 2016.08.076

27. Park HS, Dang XP (2010) Optimization of conformal cooling channels with array of baffles for plastic injection mold. Int J Precis Eng Manuf 11:879-890. https://doi.org/10.1007/s12541010-0107-Z

28. Xu X, Sachs E, Allen S (2001) The design of conformal cooling channels in injection molding tooling. Polym Eng Sci 41:12651279. https://doi.org/10.1002/pen.10827

29. Karbasian H, Tekkaya AE (2010) A review on hot stamping. J Mater Process Technol 210:2103-2118. https://doi.org/10.1016/j. jmatprotec.2010.07.019

30. Merklein M, Lechler J, Stoehr T (2008) Characterization of tribological and thermal properties of metallic coatings for hot stamping boron-manganese steels. Manuf Eng 1-3

31. Lechler J, Merklein M (2008) Hot stamping of ultra high strength steels as a key technology for lightweight construction, in: Materials Science and Technology. Pittsburgh, Pennsylvania

32. Naderi M (2007) Hot stamping of ultra high strength steels 190. 28187

33. Abdollahpoor A, Chen X, Pereira MP, Xiao N, Rolfe BF (2016) Sensitivity of the final properties of tailored hot stamping components to the process and material parameters. J. Mater. Process. Technol. 228:125-136. https://doi.org/10.1016/j.jmatprotec.2014. 11.033

34. Merklein M, Wieland M, Lechner M, Bruschi S, Ghiotti A (2016) Hot stamping of boron steel sheets with tailored properties: A review. J Mater Process Technol 228:11-24. https://doi.org/10. 1016/j.jmatprotec.2015.09.023

35. Mu Y, Wang B, Zhou J, Huang XU, Li X (2017) Hot stamping of boron steel using partition heating for tailored properties: experimental trials and numerical analysis. Metall Mater Trans A 48: 5467-5479. https://doi.org/10.1007/s11661-017-4270-z

36. Venturato G, Novella M, Bruschi S, Ghiotti A, Shivpuri R (2017) Effects of phase transformation in hot stamping of 22MnB5 high strength steel. Procedia Eng 183:316-321. https://doi.org/10. 1016/j.proeng.2017.04.045
37. Muller B, Gebauer M, Hund R, Malek R, Gerth N (2014) Metal additive manufacturing for tooling applications - laser beam melting technology increases efficiency of dies and molds. In: Metal Additive Manufacturing Conference (MAM). Wien, pp 1-14

38. Gao H, El Fakir O, Wang L, Politis DJ, Li Z (2017) Forming limit prediction for hot stamping processes featuring non-isothermal and complex loading conditions. Int J Mech Sci 131-132:792810. https://doi.org/10.1016/j.ijmecsci.2017.07.043

39. Wang A, Zhong K, El Fakir O, Liu J, Sun C, Wang LL, Lin J, Dean TA (2017) Springback analysis of AA5754 after hot stamping: experiments and FE modelling. Int J Adv Manuf Technol 89:1339-1352. https://doi.org/10.1007/s00170-0169166-3

40. El Fakir O, Wang L, Balint D, Dear JP, Lin J, Dean TA (2014) Numerical study of the solution heat treatment, forming, and indie quenching (HFQ) process on AA5754. Int J Mach Tools Manuf 87:39-48. https://doi.org/10.1016/j.ijmachtools.2014.07. 008

41. Garrett RP, Lin J, Dean TA (2005) An investigation of the effects of solution heat treatment on mechanical properties for AA 6xxx alloys: Experimentation and modelling. Int J Plast 21:1640-1657. https://doi.org/10.1016/j.ijplas.2004.11.002

42. Wang L, Strangwood M, Balint D, Lin J, Dean TA (2011) Formability and failure mechanisms of AA2024 under hot forming conditions. Mater Sci Eng A 528:2648-2656. https:// doi.org/10.1016/j.msea.2010.11.084

43. Foster AD, Dean TA, Lin J (2010) Process for forming aluminium alloy sheet component. International Patent No.: WO 2010/032002 A1.

44. Lin, J., Balint, D., Wang, L., Dean, T.A., Foster, A.D., 2011. A method of forming a component of complex shape from sheet material. UK Patent No.: GB2473298.

45. Impression Technologies Ltd (2013) HFQ technology [WWW Document].

46. Wang, L., Fakir, O. El, Sun, Y., Ji, K., Luan, X., Cai, Z., Liu, X., 2019a. A method of forming parts from sheet metal. International Patent No.: WO2019/038556.

47. Wang M, Li W, Wu Y, Li S, Cai C, Wen S, Wei Q, Shi Y, Ye F, Chen Z (2019b) High-temperature properties and microstructural stability of the AISI H13 hot-work tool steel processed by selective laser melting. Metall Mater Trans B Process Metall Mater Process Sci 50:531-542. https://doi.org/10.1007/s11663-0181442-1

48. Luan X, Zhang QL, Fakir OE, Wang LL, Gharbi MM (2017) UniForm: a pilot production line for hot/warm sheet metal forming integrated in a Cloud Based SMARTFORMING platform. In: The 3rd International Conference on Advanced High Strength Steel and Press Hardening, pp 492-497. https://doi.org/10.1142/ 9789813207301_0067

49. Smart Forming (2019) Smart forming technology platform [WWW Document].

50. Zhang Q, Luan X, Dhawan S, Politis DJ, Du Q, Fu MW, Wang K, Gharbi MM, Wang L (2019) Development of the post-form strength prediction model for a high-strength $6 \mathrm{xxx}$ aluminium alloy with pre-existing precipitates and residual dislocations. Int J Plast 119:230-248. https://doi.org/10.1016/j.ijplas.2019.03.013

51. Harrison NR, Luckey SG (2014) Hot Stamping of a B-Pillar Outer from High Strength Aluminum Sheet AA7075. SAE Int J Mater Manuf 7:2014-01-0981. https://doi.org/10.4271/2014-01-0981

52. Zhou J, Wang B, Lin J, Fu L (2013) Optimization of an aluminum alloy anti-collision side beam hot stamping process using a multiobjective genetic algorithm. Arch Civ Mech Eng 13:401-411. https://doi.org/10.1016/j.acme.2013.01.008

53. Liu X, Ji K, El Fakir O, Fang H, Gharbi MM, Wang LL (2017a) Determination of the interfacial heat transfer coefficient for a hot 
aluminium stamping process. J Mater Process Technol 247:158170. https://doi.org/10.1016/j.jmatprotec.2017.04.005

54. Liu Y, Zhu Z, Wang Z, Zhu B, Wang Y, Zhang Y (2017b) Formability and lubrication of a B-pillar in hot stamping with 6061 and 7075 aluminum alloy sheets. Procedia Eng 207:723728. https://doi.org/10.1016/j.proeng.2017.10.819

55. Song Y, Dai D, Geng P, Hua L (2017) Formability of aluminum alloy thin-walled cylinder parts by servo hot stamping. Procedia Eng 207:741-746. https://doi.org/10.1016/j.proeng.2017.10.822

56. Maeno T, Mori K, Yachi R (2017) CIRP Annals - Manufacturing technology hot stamping of high-strength aluminium alloy aircraft parts using quick heating. CIRP Ann - Manuf Technol 66:269272. https://doi.org/10.1016/j.cirp.2017.04.117

57. Milkereit B, Österreich M, Schuster P, Kirov G (2018) Dissolution and precipitation behavior for hot forming of 7021 and $7075 \mathrm{alu}-$ minum alloys. Metals (Basel) 8. https://doi.org/10.3390/ met8070531

58. Milkereit B, Wanderka N, Schick C, Kessler O (2012) Continuous cooling precipitation diagrams of Al-Mg-Si alloys. Mater Sci Eng A 550:87-96. https://doi.org/10.1016/j.msea.2012.04.033

59. Yun S, Kwon J, Cho W, Lee DC, Kim Y (2020) Performance improvement of hot stamping die for patchwork blank using mixed cooling channel designs with straight and conformal channels. Appl Therm Eng 165:114562. https://doi.org/10.1016/j. applthermaleng.2019.114562

60. Escher C, Wilzer JJ (2015) Tool steels for hot stamping of high strength automotive body parts. Int Conf Stone Concr Mach 3: 219-228

61. Tang D, Eversheim W, Schuh G (2004) Qualitative and quantitative cost analysis for sheet metal stamping. Int J Comput Integr Manuf 17:394-412.https://doi.org/10.1080/ 09511920410001662120

62. Axinte D, Dewes R (2010) High-speed milling of AISI H13 hotwork tool steel using polycrystalline cubic boron nitride ball-nose mills: From experimental investigations and empirical modelling to functional testing of the machined surfaces. Proc Inst Mech Eng Part B J Eng Manuf 224:15-24. https://doi.org/10.1243/ 09544054JEM1630

63. Gunnarsson S, Nordh LG (2002) The influence of steel grade and steel hardness on tool life when milling in hardened tool steel, in: Proceedings of the 6th International Tooling Conference - The Use of Tool Steels - Experience and Research. Karlstad, pp. 11991208.

64. Sandberg N (2017) on the machinability of high performance tool steels. Uppsala Universitet

65. Donghao LIU (2018) Die manufacturing process the best flow from idea to delivery tutor. Politecnico di Torino

66. Cortina M, Arrizubieta J, Calleja A, Ukar E, Alberdi A (2018) Case study to illustrate the potential of conformal cooling channels for hot stamping dies manufactured using hybrid process of laser metal deposition (LMD) and milling. Metals (Basel) 8:102. https://doi.org/10.3390/met8020102

67. Valls I, Casas B, Rodríguez N, Paar U (2010) Benefits from using high thermal conductivity tool steels in the hot forming of steels. Metall Ital 102:23-28

68. Lim WS, Choi HS, Ahn SY, Kim BM (2014) Cooling channel design of hot stamping tools for uniform high-strength components in hot stamping process. Int J Adv Manuf Technol 70: 1189-1203. https://doi.org/10.1007/s00170-013-5331-0

69. Mazur M, Leary M, McMillan M, Elambasseril J, Brandt M (2016) SLM additive manufacture of $\mathrm{H} 13$ tool steel with conformal cooling and structural lattices. Rapid Prototyp J 22:504-518. https://doi.org/10.1108/RPJ-06-2014-0075

70. Au KM, Yu KM (2011) Modeling of multi-connected porous passageway for mould cooling. CAD Comput Aided Des 43:9891000. https://doi.org/10.1016/j.cad.2011.02.007
71. Brooks H, Brigden K (2016) Design of conformal cooling layers with self-supporting lattices for additively manufactured tooling. Addit Manuf 11:16-22. https://doi.org/10.1016/j.addma.2016.03. 004

72. Canellidis V, Giannatsis J, Dedoussis V (2009) Genetic-algorithmbased multi-objective optimization of the build orientation in stereolithography. Int J Adv Manuf Technol 45:714-730. https:// doi.org/10.1007/s00170-009-2006-y

73. Hur J, Lee K (1998) The development of a CAD environment to determine the preferred build-up direction for layered manufacturing. Int J Adv Manuf Technol 14:247-254. https://doi.org/10. 1007/BF01199879

74. Hartunian P, Eshraghi M (2018) Effect of build orientation on the microstructure and mechanical properties of selective laser-melted Ti-6Al-4 V Alloy. J Manuf Mater Process 2:69. https://doi.org/10. 3390/jmmp2040069

75. Simonelli M, Tse YY, Tuck C (2014) Effect of the build orientation on the mechanical properties and fracture modes of SLM Ti6Al-4 V. Mater Sci Eng A 616:1-11. https://doi.org/10.1016/j. msea.2014.07.086

76. Das P, Chandran R, Samant R, Anand S (2015) Optimum part build orientation in additive manufacturing for minimizing part errors and support structures. Procedia Manuf 1:343-354. https://doi.org/10.1016/j.promfg.2015.09.041

77. Langelaar M (2018) Combined optimization of part topology, support structure layout and build orientation for additive manufacturing. Struct Multidiscip Optim 57:1985-2004. https:// doi.org/10.1007/s00158-017-1877-z

78. McClurkin JE, Rosen DW (1998) Computer-aided build style decision support for stereolithography. Rapid Prototyp J 4:4-13. https://doi.org/10.1108/13552549810197505

79. Charkaluk E, Chastand V (2018) Fatigue of additive manufacturing specimens: a comparison with casting processes. Proceedings 2:474. https://doi.org/10.3390/icem18-05352

80. Jiang C, Shan Z, Zhuang B, Zhang M, Xu Y (2012) Hot stamping die design for vehicle door beams using ultra-high strength steel. Int J Precis Eng Manuf 13:1101-1106. https://doi.org/10.1007/ s12541-012-0144-x

81. Shan Z-d, Mi-lan Z, Chao J, Xu Y, Wen-juan R (2010) Basic study on die cooling system of hot stamping process, in: International Conference on Advanced Technology of Design and Manufacture (ATDM 2010). IET, Beijing, pp 1-4. https://doi.org/10.1049/cp. 2010.1248

82. Rao N, Schumacher G, Schott N, O’Brien K (2002) optimization of cooling systems in injection molds by an easily applicable analytical model. J Reinf Plast Compos 21:451-459. https://doi.org/ 10.1106/073168402026471

83. Lei C, Cui J, Xing Z, Fu H, Zhao H (2012) Investigation of cooling effect of hot-stamping dies by numerical simulation. Phys Procedia 25:118-124. https://doi.org/10.1016/j.phpro.2012. 03.059

84. Ying X, Zhong-De S (2014) Design parameter investigation of cooling systems for UHSS hot stamping dies. Int J Adv Manuf Technol 70:257-262. https://doi.org/10.1007/s00170-013-5272-7

85. De Shan Z, Ye YS, Zhang ML, Wang BY (2013) Hot-stamping die-cooling system for vehicle door beams. Int J Precis Eng Manuf 14:1251-1255. https://doi.org/10.1007/s12541-013-0170-3

86. Steinbeiss H, So H, Michelitsch T, Hoffmann H (2007) Method for optimizing the cooling design of hot stamping tools. Prod Eng 1:149-155. https://doi.org/10.1007/s11740-007-0010-3

87. Chen J, Gong P, Liu Y, Zheng X, Ren F (2017) Optimization of hot stamping cooling system using segmented model. Int J Adv Manuf Technol 93:1357-1365. https://doi.org/10.1007/s00170017-0504-X

88. Cheng X, Wei K, He R, Pei Y, Fang D (2016) The equivalent thermal conductivity of lattice core sandwich structure: A 
predictive model. Appl Therm Eng 93:236-243. https://doi.org/ 10.1016/j.applthermaleng.2015.10.002

89. Ptochos E, Labeas G (2012) Elastic modulus and Poisson's ratio determination of micro-lattice cellular structures by analytical, numerical and homogenisation methods. J Sandw Struct Mater 14: 597-626. https://doi.org/10.1177/1099636212444285

90. Gaynor AT, Guest JK (2016) Topology optimization considering overhang constraints: Eliminating sacrificial support material in additive manufacturing through design. Struct Multidiscip Optim 54:1157-1172. https://doi.org/10.1007/s00158-016-1551-x.

91. Li Z, Wang X, Gu J, Ruan S, Shen C, Lyu Y, Zhao Y (2018) Topology optimization for the design of conformal cooling system in thin-wall injection molding based on BEM. Int J Adv Manuf Technol 94:1041-1059. https://doi.org/10.1007/s00170-0170901-1

92. Leary M, Merli L, Torti F, Mazur M, Brandt M (2014) Optimal topology for additive manufacture: a method for enabling additive manufacture of support-free optimal structures. Mater Des 63: 678-690. https://doi.org/10.1016/j.matdes.2014.06.015

93. Brackett D, Ashcroft I, Hague R (2011) Topology optimization for additive manufacturing. 22nd Annu. Int. Solid Free. Fabr. Symp. An Addit. Manuf. Conf. SFF 2011:348-362

94. Naganathan A, Penter L (2012) Hot Stamping, in: Altanm, T., Tekkaya, E. (Eds.), sheet metal forming - processes and applications. ASM Internation, pp 133-156

95. Hoffmann H, So H, Steinbeiss H (2007) Design of hot stamping tools with cooling system. CIRP Ann - Manuf Technol 56:269272. https://doi.org/10.1016/j.cirp.2007.05.062

96. Zheng K, Lee J, Xiao W, Wang B, Lin J (2018) Experimental investigations of the in-die quenching efficiency and die surface temperature of hot stamping aluminium alloys. Metals (Basel) 8: 231. https://doi.org/10.3390/met8040231

97. Gumpel P, Bogatzky T, Huber A, Geigges B (2002) Comparison of different characteristics of modern hot-work tool steels. 6 th Int Tool Conf:3-16

98. Benedyk JC (2008) High Performance Alloy Database- H13.

99. Grellier A, Siaut M (2002) A new hot work tool steel for high temperature and high stress service conditions. 6th Int. Tool. Conf. $39-48$.

100. Mueller, C., Schruff, I., 2016. Steel selection contributing to wear reduction of forging dies.

101. Rovalma (2009) Technical card HTCS-130WU.

102. Qamar SZ (2015) Heat treatment and mechanical testing of AISI H11 Steel. Key Eng Mater 656-657:434-439. https://doi.org/10. 4028/www.scientific.net/KEM.656-657.434

103. Otai Steel (2019) 1.2367 Mechanical Properties [WWW Document]. URL http://www.otaisteel.com/din-1-2367-hotwork-tool-steel/ (accessed 1.23.19).

104. Rovalma (2017) HTCS 130 Thermo-mechanical Properties [WWW Document]. URL http://rovalma.com/wp-content/ uploads/2017/06/HTCS®-130WU.pdf (accessed 1.23.19).

105. Orsa Ltd (2016) HTCS-130 Thermo-mechanical Properties [WWW Document]. URL http://www.orsa-ltd.com/upload/files/ katalog/Rovalma/ORSA-HTCS-130-sicak-is-toz-metal.pdf (accessed 1.23.19).

106. Schruff I (2012) The tool steel producer's contribution to successful die casting of structural components. Metall Ital 104:37-43

107. Li S, Zhou L, Wu X, Zhang Y, Li J (2016) The influence of thermal conductivity of die material on the efficiency of hotstamping pProcess. J Mater Eng Perform 25:4848-4867. https:// doi.org/10.1007/s11665-016-2332-9

108. Rahn, R., Schruff, I., 2015. The selection of tool steels for hotstamping tools with respect to increased loads.

109. Ye YS, De Shan Z, Wang BY, Jiang C, Zhuang BL (2014) A material selection criterion for hot-stamping dies. Appl Mech
Mater 490-491:25-28. https://doi.org/10.4028/www.scientific. net/AMM.490-491.25

110. ASTM International (2013) F2792-12a - Standard terminology for additive manufacturing technologies. Rapid Manuf Assoc:10-12. https://doi.org/10.1520/F2792-12A.2

111. DebRoy T, Wei HL, Zuback JS, Mukherjee T, Elmer JW, Milewski JO, Beese AM, Wilson-Heid A, De A, Zhang W (2018) Additive manufacturing of metallic components Process, structure and properties. Prog Mater Sci 92:112-224. https://doi.org/10.1016/j.pmatsci.2017.10.001

112. Renishaw (2017) Renishaw conformal cooling solutions prove a boost to moulding productivity.

113. Roland Berger (2019) Additive manufacturing - Taking metal 3D printing to the next level [WWW Document]. URL https://www. slideshare.net/MartinErharter/additive-manufacturing-takingmetal-3-d-printing-to-the-next-level-study-by-roland-berger200943228 (accessed 5.10.20).

114. EOS GmbH (2019a) Material Datasheet - Aluminium AlSi10Mg [WWW Document]. URL https://www.eos.info/material-m (accessed 1.20.19).

115. SLM Solutions GmbH (2019) Material Data Sheet of Available Powders from SLM Solutions [WWW Document]. 10.2116/ bunsekikagaku.53.1021

116. Renishaw (2019a) Material data sheet -AlSi10Mg [WWW Document]. URL https://www.renishaw.com/en/data-sheetsadditive-manufacturing\%2D\%2D17862 (accessed 1.20.19).

117. EOS GmbH (2019b) Material data sheet - Cobalt Chrome MP1 [WWW Document]. URL https://www.eos.info/material-m (accessed 1.20.19)

118. Concept Laser GmbH (2019a) Material Datasheet CL 50WS [WWW Document]. URL https://www.concept-laser.de/en/ products/materials.html (accessed 1.20.19).

119. Renishaw (2019b) Material data sheet - Maraging steel [WWW Document]. URL https://www.renishaw.com/en/data-sheetsadditive-manufacturing\%2D\%2D17862 (accessed 1.20.19).

120. EOS GmbH (2019c) Material Data Sheet - Maraging Steel MS1 [WWW Document]. URL https://www.eos.info/material-m (accessed 1.20.19).

121. Concept Laser GmbH (2019b) Material Datasheet - CL 100NB [WWW Document]. URL https://www.concept-laser.de/en/ products/materials.html (accessed 1.20.19).

122. EOS GmbH (2019d) Material Data Sheet - NickelAlloy HX [WWW Document]. URL https://www.eos.info/material-m (accessed 1.20.19).

123. EOS GmbH (2019e) Material data sheet - EOS Nickel Alloy IN625 [WWW Document]. URL https://www.eos.info/material$\mathrm{m}$ (accessed 1.20.19).

124. Renishaw (2019c) Material data sheet - IN625 [WWW Document]. URL https://www.renishaw.com/en/data-sheetsadditive-manufacturing\%2D\%2D17862 (accessed 1.20.19).

125. EOS GmbH (2019f) Material Data Sheet IN718 [WWW Document]. URL https://www.eos.info/material-m (accessed 1. 20.19).

126. Renishaw (2019d) Material data sheet -Renishaw IN718 [WWW Document]. URL https://www.renishaw.com/en/data-sheetsadditive-manufacturing\%2D\%2D17862 (accessed 1.20.19).

127. Renishaw (2019e) Material data sheet - Stainless Steel 316 L [WWW Document]. URL https://www.renishaw.com/en/datasheets-additive-manufacturing\%2D\%2D17862 (accessed 1.20. 19).

128. Concept Laser GmbH (2019c) Material Datasheet - Stainless Steel CL 20ES [WWW Document]. URL https://www.concept-laser.de/ en/products/materials.html (accessed 1.20.19).

129. EOS GmbH (2019g) Material data sheet - Stainless Steel 316 L [WWW Document]. URL https://www.eos.info/material-m (accessed 1.20.19). 
130. Renishaw (2019f) Material data sheet -Ti6Al4V [WWW Document]. URL https://www.renishaw.com/en/data-sheetsadditive-manufacturing\%2D\%2D17862 (accessed 1.20.19).

131. Concept Laser GmbH (2019d) Material Datasheet - CL Ti47 [WWW Document]. URL https://www.concept-laser.de/en/ products/materials.html (accessed 1.20.19).

132. Valls I, Hamasaiid A, Padré A (2018) New approaches to thermal tool performance, cooling and machining strategy: The strongly correlated triple that determines the cost effectiveness of the process. IOP Conf Ser Mater Sci Eng:418. https://doi.org/10.1088/ 1757-899X/418/1/012013

133. Gibson I, Rosen DW, Stucker B (2010) Additive manufacturing technologies. Springer US, Boston, MA. https://doi.org/10.1007/ 978-1-4419-1120-9

134. Spears TG, Gold SA (2016) In-process sensing in selective laser melting (SLM) additive manufacturing. Integr Mater Manuf Innov 5:16-40. https://doi.org/10.1186/s40192-016-0045-4

135. Gong H (2013) Generation and detection of defects in metallic parts fabricated by selective laser melting and electron beam melting and their effects on mechanical properties. University of Louisville. https://doi.org/10.18297/etd/515

136. Hitzler L, Hirsch J, Heine B, Merkel M, Hall W, Öchsner A (2017) On the anisotropic mechanical properties of selective laser-melted stainless steel. Materials (Basel):10. https://doi.org/10.3390/ ma10101136

137. Deev AA, Kuznetcov PA, Petrov SN (2016) Anisotropy of mechanical properties and its correlation with the structure of the stainless steel $316 \mathrm{~L}$ produced by the SLM method. Phys Procedia 83:789-796. https://doi.org/10.1016/j.phpro.2016.08. 081

138. Kunze K, Etter T, Grässlin J, Shklover V (2014) Texture, anisotropy in microstructure and mechanical properties of IN738LC alloy processed by selective laser melting (SLM). Mater Sci Eng A 620:213-222. https://doi.org/10.1016/j.msea.2014.10.003

139. Song B, Dong S, Zhang B, Liao H, Coddet C (2012) Effects of processing parameters on microstructure and mechanical property of selective laser melted Ti6A14V. Mater Des 35:120-125. https:// doi.org/10.1016/j.matdes.2011.09.051

140. Zhang B, Liao H, Coddet C (2012a) Effects of processing parameters on properties of selective laser melting $\mathrm{Mg}-9 \% \mathrm{Al}$ powder mixture. Mater Des 34:753-758. https://doi.org/10.1016/j. matdes.2011.06.061

141. Gu D, Shen Y (2008) Processing conditions and microstructural features of porous $316 \mathrm{~L}$ stainless steel components by DMLS. Appl Surf Sci 255:1880-1887. https://doi.org/10.1016/j.apsusc. 2008.06.118

142. Guan K, Wang Z, Gao M, Li X, Zeng X (2013) Effects of processing parameters on tensile properties of selective laser melted 304 stainless steel. Mater Des Elsevier Ltd 50:581-586. https:// doi.org/10.1016/j.matdes.2013.03.056

143. Hebert RJ (2016) Viewpoint: metallurgical aspects of powder bed metal additive manufacturing. J Mater Sci 51:1165-1175. https:// doi.org/10.1007/s10853-015-9479-x

144. Meier, C., Weissbach, R., Weinberg, J., Wall, W.A., Hart, A.J., 2018. Critical influences of particle size and adhesion on the powder layer uniformity in metal additive manufacturing.

145. Andreau O, Peyre P, Penot JD, Koutiri I, Dupuy C, Pessard E, Saintier N (2017) Deterministic defect generation in selective laser melting: parametric optimization and control. Lasers Manuf WLT eV:1-11

146. Ma M, Wang Z, Gao M, Zeng X (2015) Layer thickness dependence of performance in high-power selective laser melting of 1Cr18Ni9Ti stainless steel. J Mater Process Technol 215:142150. https://doi.org/10.1016/j.jmatprotec.2014.07.034
147. Zhang B, Zhu L, Liao H, Coddet C (2012b) Improvement of surface properties of SLM parts by atmospheric plasma spraying coating. Appl Surf Sci 263:777-782. https://doi.org/10.1016/j. apsusc.2012.09.170

148. Wang XJ, Zhang LC, Fang MH, Sercombe TB (2014) The effect of atmosphere on the structure and properties of a selective laser melted Al-12Si alloy. Mater Sci Eng A 597:370-375. https://doi. org/10.1016/j.msea.2014.01.012

149. Zhang B, Dembinski L, Coddet C (2013) The study of the laser parameters and environment variables effect on mechanical properties of high compact parts elaborated by selective laser melting 316 L powder. Mater Sci Eng A 584:21-31. https://doi.org/10. 1016/j.msea.2013.06.055

150. Masmoudi A, Bolot R, Coddet C (2015) Investigation of the laserpowder-atmosphere interaction zone during the selective laser melting process. J Mater Process Technol 225:122-132. https:// doi.org/10.1016/j.jmatprotec.2015.05.008

151. Kempen K, Yasa E, Thijs L, Kruth JP, Van Humbeeck J (2011) Microstructure and mechanical properties of selective laser melted 18Ni-300 steel. Phys Procedia 12:255-263. https://doi.org/10. 1016/j.phpro.2011.03.033

152. Holzweissig MJ, Taube A, Brenne F, Schaper M, Niendorf T (2015) Microstructural characterization and mechanical performance of hot work tool steel processed by selective laser melting. Metall Mater Trans B Process Metall Mater Process Sci 46:545549. https://doi.org/10.1007/s11663-014-0267-9

153. Casalino G, Campanelli SL, Contuzzi N, Ludovico AD (2015) Experimental investigation and statistical optimisation of the selective laser melting process of a maraging steel. Opt Laser Technol 65:151-158. https://doi.org/10.1016/j.optlastec.2014.07. 021

154. Mertens R, Vrancken B, Holmstock N, Kinds Y, Kruth JP, Van Humbeeck J (2016) Influence of powder bed preheating on microstructure and mechanical properties of $\mathrm{H} 13$ tool steel SLM parts. Phys Procedia 83:882-890. https://doi.org/10.1016/j. phpro.2016.08.092

155. Krell J, Röttger A, Geenen K, Theisen W (2018) General investigations on processing tool steel X40CrMoV5-1 with selective laser melting. J Mater Process Technol 255:679-688. https://doi. org/10.1016/j.jmatprotec.2018.01.012

156. Bai Y, Yang Y, Xiao Z, Wang D (2018) Selective laser melting of maraging steel: mechanical properties development and its application in mold. Rapid Prototyp J 24:623-629. https://doi.org/10. 1108/RPJ-05-2017-0104

157. Tan C, Zhou K, Kuang M, Ma W, Kuang T (2018) Microstructural characterization and properties of selective laser melted maraging steel with different build directions. Sci Technol Adv Mater 19: 746-758. https://doi.org/10.1080/14686996.2018.1527645

158. Narvan M, Al-Rubaie KS, Elbestawi M (2019) Process-structureproperty relationships of AISI H13 tool steel processed with selective laser melting. Materials (Basel) 12:2284. https://doi.org/10. 3390/ma12142284

159. Croccolo D, De Agostinis M, Fini S, Olmi G, Robusto F, ĆirićKostić S, Morača S, Bogojević N (2019) Sensitivity of direct metal laser sintering maraging steel fatigue strength to build orientation and allowance for machining. Fatigue Fract Eng Mater Struct 42:374-386. https://doi.org/10.1111/ffe.12917

160. Mugwagwa, Yadroitsev, Matope (2019) Effect of process parameters on residual stresses, distortions, and porosity in selective laser melting of maraging steel 300. Metals (Basel) 9:1042. https://doi.org/10.3390/met9101042

Publisher's note Springer Nature remains neutral with regard to jurisdictional claims in published maps and institutional affiliations. 